\title{
Rock-water interaction processes based on geochemical modeling and remote sensing applications in hyper-arid environment: cases from the southeastern region of Egypt
}

Mohamed Yousif $f^{*}$ (D) and Abdel Hameed M. El-Aassar ${ }^{2}$

\begin{abstract}
Background: The interaction between rocks and groundwater can be considered as multi-faceted processes in hydrogeology where the groundwater chemistry can be resulted from leaching and/or minerals dissolution. The scientific approach of this study based on testing the contribution of remote sensing in providing information related to rock-groundwater interaction along with the outputs of the geochemical model. The current research aims to explore the impacts of lithologic nature and structural geology on the groundwater chemistry. The mentioned objective is significant for the future sustainable development of groundwater in hyper-arid regions. Therefore, both geology and geochemistry of water-bearing formations along the flow path to the studied aquifers were identified. The area was chosen as an example from hyper-arid region to carry out this scientific approach.

Results: The obtained results indicate the existence of three main aquifers: Quaternary alluvial (salinity $1253 \mathrm{mg} / \mathrm{l}$ to 18,854 mg/l), Nubian Sandstone (salinity $311 \mathrm{mg} / \mathrm{l}$ to 14,388 mg/l), and fractured basement (salinity $320 \mathrm{mg} / \mathrm{l}$ to 19,375 mg/ I). The results of speciation modeling showed that studied aquifers are supersaturated with gibbsite, goethite, hematite, magnetite, aragonite, calcite, dolomite, and alunite. Nubian aquifer specifically has homogeneity results due to the similarity of water-bearing and geology of watersheds (ferruginous sandstone and ironstone). Remote sensing data and digital elevation model analyses were used for generation of the thematic layers which is affecting the groundwater occurrences and quality such as geology, geomorphology, structural lineaments, slope, flow direction, drainage lines, and elevations.

Conclusions: The current research concluded that the groundwater chemistry can be a signature of the rock-water interaction. The potential implications of the research are represented through a priority map for groundwater exploration for both hydro-geophysical investigation and testing wells in order to evaluate the groundwater capabilities where the data from the recorded wells were used to calibrate this map.
\end{abstract}

Keywords: Rock-water interaction, Hydro-geochemistry, Groundwater, Geology, Remote sensing, GIS

\footnotetext{
*Correspondence: yousif_mohamed80@daad-alumni.de

'Geology Department, Desert Research Centre, P.O. Box 11753, El Matariya,

Cairo, Egypt

Full list of author information is available at the end of the article
} 


\section{Background}

Water scarcity in the hyper-arid region, such as the southeastern Egypt, represents the main challenge to the hydro-geologists where they should work to evaluate and protect any source of water. The deficiency of water resources in these hyper-arid regions could affect different activities (including economics and humans); therefore, numerous efforts are essential to avoid any of the expected disasters and conflicts which might occur as a result of limited water resources (Gheith and Sultan 2002). The decision-makers in Egypt have an important challenge to manage water resource for sustainable development (Ahmed and Abdelmohsen 2018).In this regard, the consideration of the processes which affect groundwater and its chemistry through rocks interactions becomes critical and necessary. Water lack is the main problem affecting the sustainable development plans in the southeastern region of Egypt where the water delivered to the Red Sea Governorate is either from the Nile River through pipes or depending on seawater desalinization (Abdel Moneim 2005). The precipitation is negligible over the South Eastern Desert without any source of recharge (e.g., Lake Nasser and Northern Sudan Platform) (Ahmed and Abdelmohsen 2018). Accordingly, groundwater is considered as an alternative solution to face these problems, and therefore, the area attracted many authors such as Abdel Moneim (2005), Yousef et al. (2009), Shawky et al. (2012), Soussa et al. (2012), and Khalil (2014) to investigate geology and water resources. The groundwater contains different types of minerals carried in solution where the types and concentration of these minerals are mainly conditional on multi-factors such as rocks chemistry, surface and groundwater interactions, the geologic setting of the preferred pathways for groundwater flow, and any other sources for water pollution. The groundwater chemistry represents the final product of the interaction between water and rocks belonging to different geological times. These interpret why groundwater contains varieties of many dissolved chemical constituents with different types and concentrations. The main objective of the current research is to explore the impacts of lithologic nature and structural geology on the groundwater chemistry. The mentioned objective is significant for the future sustainable development of groundwater in hyper-arid regions. In this context, the research has been carried out to investigate the processes resulted from the interaction between different rocks and groundwater. In this manuscript, rock terms are expressing about two types of meaning: the water-bearing formation and the rocks which formed the watersheds that affect the groundwater. The presented scientific approach of this study is based on exploring the integration of remote sensing and satellite applications in providing spatial information related to rock-water interaction processes along with the outputs and results of the geochemical model.

\section{Site descriptions}

The study area is falling in the hyper-arid zone of Egypt according to the aridity index map (ICARDA 2010) which reveals the shortage of water resources supplied to this area. This is compatible with Gravity Recovery and Climate Experiment (GRACE) data which proved high groundwater depletion rates over the southern parts of Egypt and Libya (Mohamed et al. 2017). The southeastern region of Egypt represents one of the promising regions which is not subjected to intensive development projects yet due to the scarcity of water or inability to use. The area under investigation covers about 22,000 $\mathrm{km}^{2}$ and is located along the Red Sea coast as a part of the Eastern Desert of Egypt (Fig. 1). The study area lies between latitude $22^{\circ} \mathrm{N}$ and $23^{\circ} 40^{\prime} \mathrm{N}$ and longitude $34^{\circ} 50^{\prime} \mathrm{E}$ and $37^{\circ} \mathrm{E}$. The temperature reaches its maximum in the summer and ranges between 45 and $50{ }^{\circ} \mathrm{C}$ (Ageeb et al. 2007). The rainfall plays an important role as it is considered the main source for the aquifer recharge. The average annual rainfall ranges from 3 to $50 \mathrm{~mm} /$ year (Embaby et al. 2016), while relative humidity ranges between 28 and 52\% (Hassanein et al. 2004).

\section{Geomorphology}

The study area can be classified into the following geomorphic unit, as shown in (Fig. 2):

- Coastal plain-it extends westward of the Red Sea shoreline for a distance ranging from 5 to $25 \mathrm{~km}$. The plain is covered by sand sheets, alluvial, and deltaic deposits. Along the shoreline, the plain is characterized by the presence of sabkha patches. It is partly covered by bushes and scrubs.

- Red Sea terrains-it borders the coastal plain and partly the Piedmont Plain. The Red Sea terrains are covered by the mountains oriented in a northwestsoutheast direction parallel to the Red Sea shoreline. The elevation is variable from 388 to $1419 \mathrm{~m}$ above sea level. The slope ranges from 15 to $30 \mathrm{~m} / \mathrm{km}$ due east.

- Isolated hills-few isolated hills are spreading over the study area, such as Gabal Umm Rasin and Gebel Elba. These hills are composed mainly of Precambrian basement rocks of different types.

- Sedimentary blocks - these blocks are located in a limited area in the west side where it is composed of Cretaceous rocks belonging to Nubian Sandstone.

- Piedmont Plain - this unit is controlled by the action of drainage basins which dissected the Red Sea terrains and attains to expand the distance between each of the coastal plain and Red Sea terrains. This unit is mainly covered by alluvial deposits and natural vegetation. 


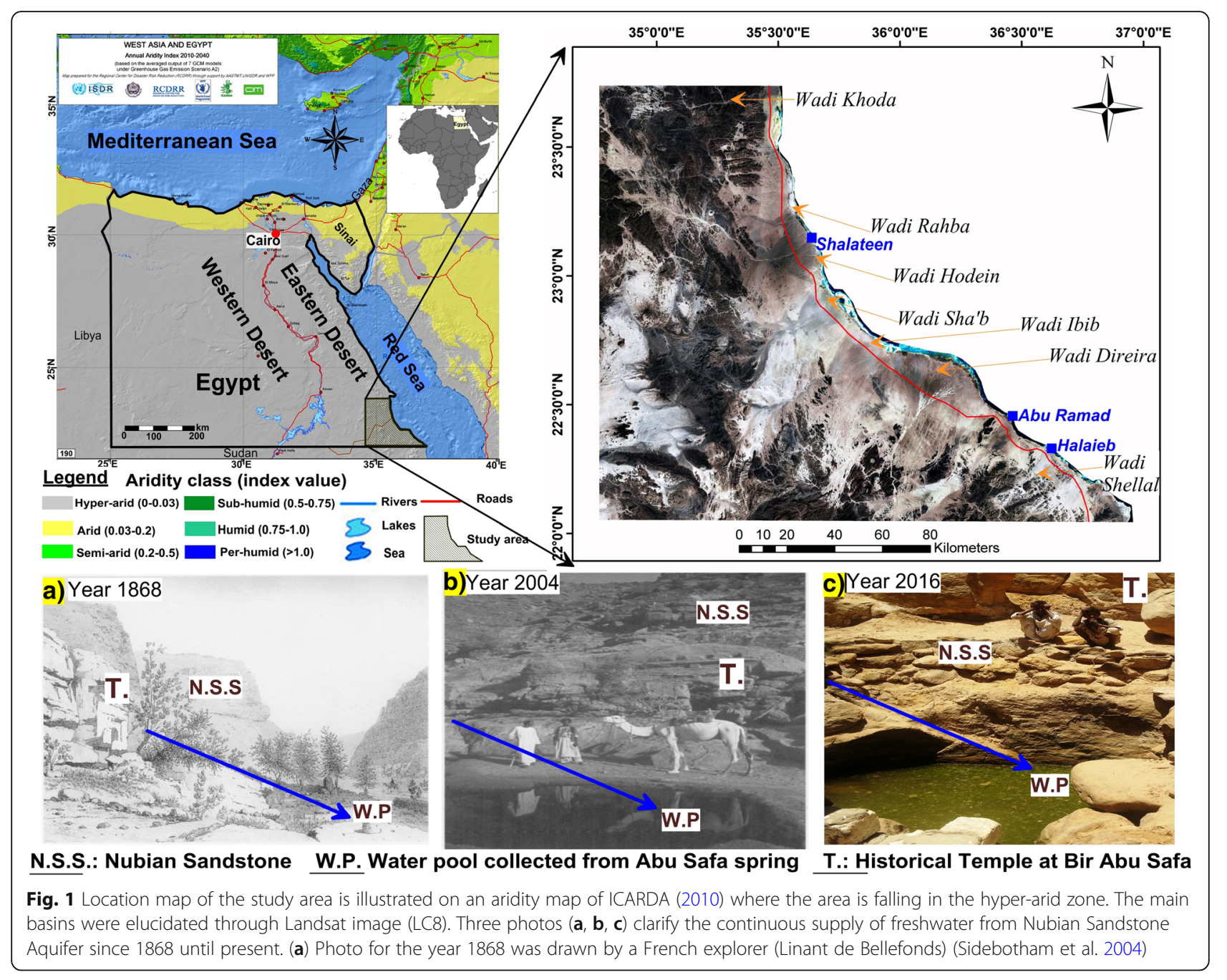

- Wadies and alluvial fans-the area under consideration is dissected by about nine main wadies which drain their surface water to the Red Sea eastwards. Most of these wadies are of small areas and short lengths.

\section{Geology of the study area}

To the west of the coastal zone, the area is covered completely (except the area of sedimentary blocks) by basement rocks, which consist mainly of granites, gneisses, schists, and quartzite of Precambrian age (Fig. 3). These basement rocks are overlain non-conformably by about $430 \mathrm{~m}$ of thick sandstone succession of Nubian facies (Elewa (2000). The sandstones consist of three formations, namely Abu-Agag, Timsah, and Umm Barmeil formations at the top. Towards the southwest, the sandstone in general dips due east and southeast. Isolated patches of Miocene sediments are located as rare exposures which consist mainly of alternating limestone and marl. Quaternary sediments comprising wadi fills and alluvial wadi deposits cover a vast area. Most of the wadies are filled with alluvial deposits with a thickness that varies between few meters and about $20 \mathrm{~m}$. Generally, the thickness increases from west to east. Numerous traverse faults have NW-SE and $\mathrm{E}-\mathrm{W}$ direction. On the other hand, a small group of minor faults exists in a NE-SW direction.

\section{Methods}

\section{Fieldwork}

During fieldwork, the geomorphologic and geologic settings of the study area were determined. Thirty sites of the study area were investigated in detail with regard to geology where the surface outcrops were identified. A total of 75 rock samples from different geological units were collected and described. The field data were used for an area-wide interpretation based on Landsat satellite images and geologic map (Conoco 1987). Also, a field trip was achieved during the summer of 2016. Though this fieldwork, the groundwater samples have been collected (37 groundwater samples representing three aquifers). The site locations have been acquired 


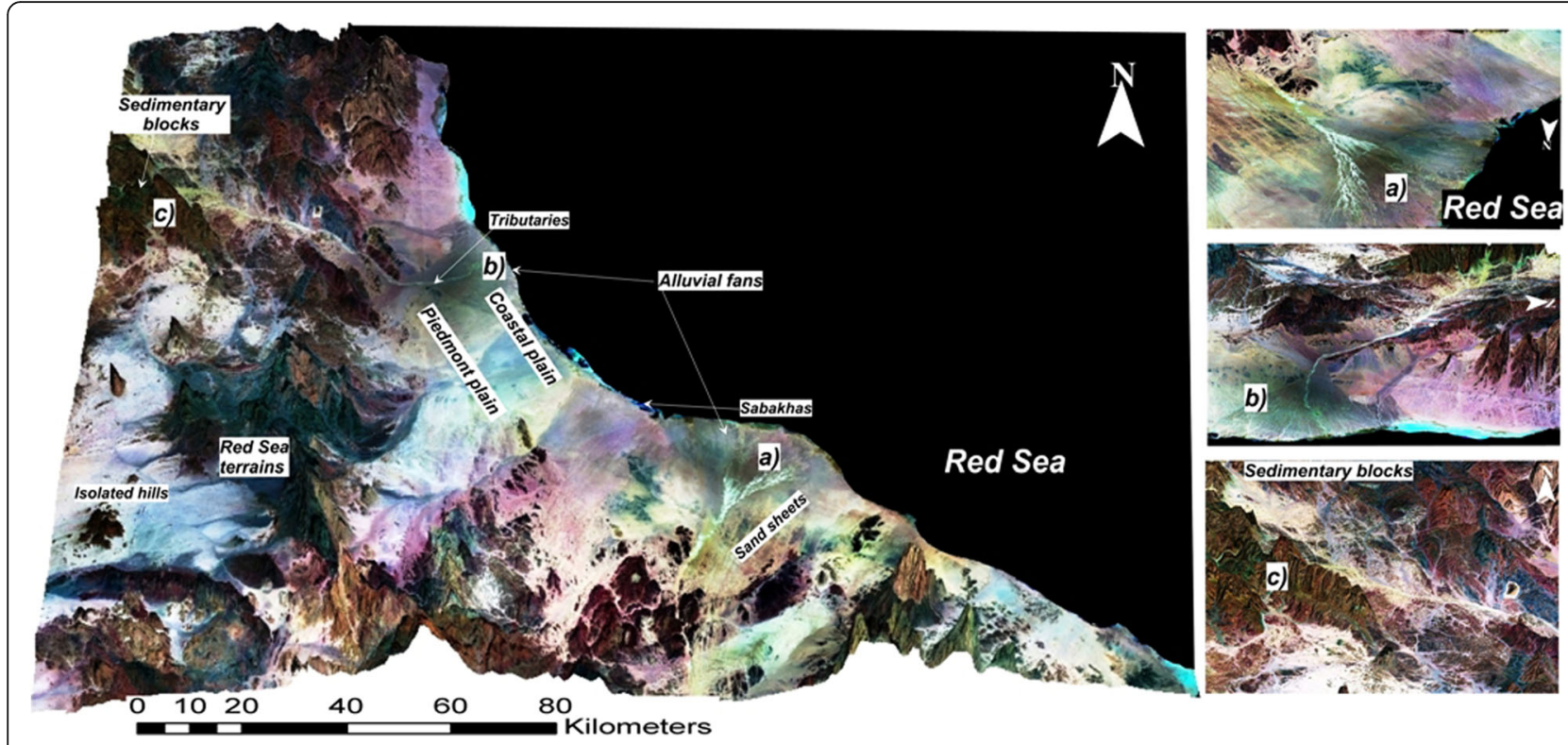

Fig. 2 Three-dimensional (3D) map showing the main landforms units of the study area (SRTM-1 overlaid by LANDSAT8). $\mathbf{a}$ and $\mathbf{b}$ are showing two of the typical alluvial fans existing in the study area. $\mathbf{c}$ is showing the sedimentary blocks which consists of Nubian sandstone

using Global Positing System (GPS), while other measurements including reduction potential (redox potential, oxidation/reduction potential, "Eh"), the hydrogen ion concentration $(\mathrm{pH})$, and the electrical conductivity (EC) were achieved in situ. Also, the hydrological data including depth to water table, total well depth, and water-bearing formations, as well as corresponding geomorphologic units, were also determined. The main factors which affect the groundwater quality and occurring were elucidated in the site where each water sample has a special case which subjected to investigation.

\section{Chemical analyses}

The total of 37 groundwater samples was analyzed at the water analysis unit of the central laboratory of Desert Research Center (DRC, Cairo, Egypt) according to ASTM 2002. The chemical analyses of the collected water samples included the determination of EC, total dissolved salts (TDS), $\mathrm{pH}$, and concentrations of major cations $\left(\mathrm{Na}^{+}, \mathrm{K}^{+}, \mathrm{Mg}^{2+}, \mathrm{Ca}^{2+}\right)$ and major anions $\left(\mathrm{Cl}^{-}\right.$, $\mathrm{SO}_{4}{ }^{2-}, \mathrm{CO}_{3}{ }^{2-}, \mathrm{HCO}_{3}{ }^{-}$) by ion chromatography (ICS-1100, Dionex, Sunnyvale, CA, USA). Also, the trace element $(\mathrm{Al}, \mathrm{B}, \mathrm{Cd}, \mathrm{Co}, \mathrm{Cr}, \mathrm{Cu}, \mathrm{Fe}, \mathrm{Mn}, \mathrm{Mo}, \mathrm{Ni}, \mathrm{Pb}, \mathrm{Ti}$, $\mathrm{Sr}, \mathrm{P}, \mathrm{V}$, and $\mathrm{Zn}$ ) concentrations of the water samples were determined using inductively coupled argon plasma (ICAP, Thermo 6500).

\section{Geochemical modeling and rocks geochemistry}

The obtained chemical analyses which included the concentrations of both major and trace elements are repressing the input data for the geochemical modeling of the PHREEQC code (Parkhurst and Appelo 1999; USGS). The PHREEQC code is used to calculate the saturation indices (SI) for minerals of interest, where this index determines whether a solution has a thermodynamic potential for further dissolution or precipitation of a mineral. The saturation indices (SI) of the relevant mineral are determined through the equation $\mathrm{SI}=\log$ (IAP/KT), where IAP is the ion activity products and KT is the solubility product of a mineral for a given temperature. The other parameters such as Eh and $\mathrm{pH}$ were also included in the database before the model running. The outputs of the model were tabulated where we focused on the minerals that saturated the studied groundwater. On the other hand, the geochemistry of the water-bearing formation and watersheds in the study area were obtained from different sources which include the works of Hassan (2015), Abd El-Naby and Frisch (2006), Khalil (1997), Farouk et al. (2015), and Shahin et al. (2016).

\section{GIS and remote sensing}

The digital elevation model (DEM) of the Shuttle Radar Topography Mission (SRTM-C) and the Enhanced Thematic Mapper Plus (ETM+) images were used to obtain data for the current research. The obtained data from the satellite images was employed for the visual interpretation of surface features and geology as well as the structural lineaments. All DEM data and satellite images were projected to the Universal Transverse Mercator (UTM) with the WGS84 datum. After processing of SRTM-C data by constructing a mosaic to extract the 


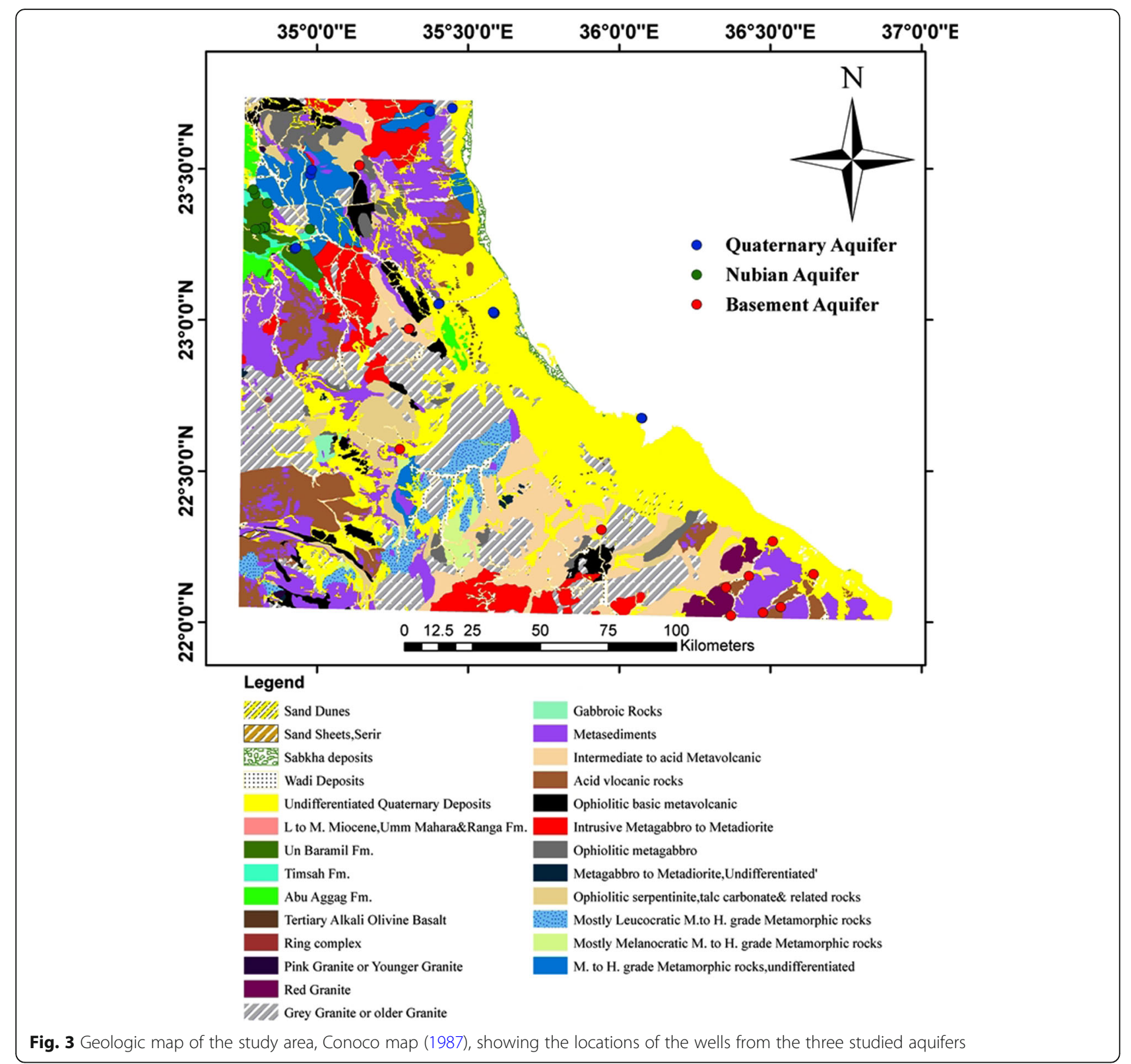

watersheds, the hydrology tools of ESRI Arc GIS v.10.4 were used to identify and fill all sinks in the resulting mosaic. Many GIS data layers were obtained through the analyses of DEM including watersheds, slope, flow direction, drainage networks, elevation, and aspect as well as the three-dimensional layer (3D) to illustrate the main landforms as well as geological and geomorphological units. Landsat GeoCover ETM+ (2000) with a spatial resolution of $14.5 \mathrm{~m}$ (band combination 742) was used with the geological map of (Conoco 1987) to determine the geology of the study area. Structural lineaments were extracted through band combination (741 and 754 of the ETM+) where the edge detection filtering in ERDAS IMAGIN 9.3 depends on the variation of digital pixel values. The geological map was also used to elucidate the lineaments structures (faults and/or fractures).

\section{Results}

Results are presented according to the before-mentioned workflow.

\section{Groundwater occurrences}

In the current study, three aquifers were chosen to be subjected for investigation where they are providing some suitable groundwater (Table 1). These aquifers are from young to old as follows: 
Table 1 Hydrogeological data of the wells tapping the studied aquifers

\begin{tabular}{|c|c|c|c|c|c|c|c|}
\hline \multirow[t]{2}{*}{ Well no. } & \multirow[t]{2}{*}{ Long. (E) } & \multirow[t]{2}{*}{ Lat. (N) } & \multicolumn{2}{|l|}{ Aquifer } & \multirow{2}{*}{$\begin{array}{l}\text { Total Depth } \\
\text { (m) }\end{array}$} & \multirow{2}{*}{$\begin{array}{l}\text { Depth to } \\
\text { water (m) }\end{array}$} & \multirow{2}{*}{$\begin{array}{l}\text { TDS } \\
(\mathrm{mg} / \mathrm{l})\end{array}$} \\
\hline & & & Formation & Type of drilling & & & \\
\hline 1 & 35.448 & 23.701 & \multirow[t]{11}{*}{ Alluvial } & Hand-dug & 20 & 12.35 & 2427 \\
\hline 2 & 35.374 & 23.691 & & Hand-dug & 20 & 14 & 2153 \\
\hline 3 & 34.978 & 23.481 & & Hand-dug & - & 6.53 & 2068 \\
\hline 4 & 34.983 & 23.496 & & Hand-dug & 15 & 10.3 & 1253 \\
\hline 5 & 36.076 & 22.675 & & Hand-dug & 2 & 1.35 & 8386 \\
\hline 6 & 36.074 & 22.675 & & Hand-dug & 2 & 1.05 & 9750 \\
\hline 7 & 35.587 & 23.023 & & Hand-dug & 25 & 20.3 & 11,053 \\
\hline 8 & 35.586 & 23.022 & & Hand-dug & 25 & 20.2 & 18,854 \\
\hline 9 & 35.583 & 23.026 & & Hand-dug & - & 20 & 10,095 \\
\hline 10 & 35.405 & 23.054 & & Hand-dug & 30 & 23.4 & 7880 \\
\hline 11 & 35.402 & 23.053 & & Hand-dug & 30 & 23.3 & 6446 \\
\hline 12 & 34.926 & 23.236 & \multirow{12}{*}{$\begin{array}{l}\text { Nubian } \\
\text { Sandstone }\end{array}$} & Drilled & 120 & 24.5 & 776 \\
\hline 13 & 34.931 & 23.239 & & Drilled & 150 & 25 & 14,388 \\
\hline 14 & 34.830 & 23.307 & & Drilled & 87 & 26.9 & 757 \\
\hline 15 & 34.820 & 23.300 & & Drilled & 90 & 24.7 & 778 \\
\hline 16 & 34.825 & 23.320 & & Drilled & 310 & 25.93 & 915 \\
\hline 17 & 34.811 & 23.301 & & Drilled & 93 & 28 & 943 \\
\hline 18 & 34.976 & 23.301 & & Spring & \multirow[t]{6}{*}{ Flowing } & & 341 \\
\hline 19 & 34.796 & 23.300 & & Spring & & & 425 \\
\hline 20 & 34.837 & 23.386 & & Spring & & & 356 \\
\hline 21 & 34.800 & 23.400 & & Spring & & & 311 \\
\hline 22 & 34.795 & 23.416 & & Spring & & & 346 \\
\hline 23 & 34.789 & 23.431 & & Spring & & & 579 \\
\hline 24 & 35.140 & 23.512 & \multirow{14}{*}{$\begin{array}{l}\text { Fractured } \\
\text { basement }\end{array}$} & Hand-dug & 9.5 & 4.7 & 320 \\
\hline 25 & 35.141 & 23.511 & & Hand-dug & 10 & 5.17 & 353 \\
\hline 26 & 35.941 & 22.306 & & Hand-dug & 29 & 28.35 & 3522 \\
\hline 27 & 35.274 & 22.572 & & Hand-dug & 17 & 14.5 & 502 \\
\hline 28 & 36.643 & 22.159 & & Hand-dug & 24 & 20.3 & 19,375 \\
\hline 29 & 36.536 & 22.051 & & Hand-dug & 22 & 18.09 & 817 \\
\hline 30 & 36.534 & 22.050 & & Hand-dug & 15 & 10.6 & 1139 \\
\hline 31 & 36.475 & 22.032 & & Hand-dug & 30 & 27 & 1027 \\
\hline 32 & 36.369 & 22.022 & & Hand-dug & 33 & 29.5 & 4289 \\
\hline 33 & 36.353 & 22.115 & & Hand-dug & 29 & 26 & 2079 \\
\hline 34 & 36.429 & 22.153 & & Hand-dug & 25 & 22 & 4986 \\
\hline 35 & 36.508 & 22.267 & & Hand-dug & 12 & 8 & 6151 \\
\hline 36 & 35.307 & 22.971 & & Hand-dug & 4.5 & 1.4 & 5138 \\
\hline 37 & 35.304 & 22.970 & & Hand-dug & 3.5 & 1.4 & 13,673 \\
\hline
\end{tabular}

\section{Quaternary aquifer}

The aquifer is composed of sands, mudstone, and different sizes of gravels (granules, pebbles, and boulders) derived from the basement rocks especially that located along the surface water path and in the vicinities of the wells (Fig. 4). This aquifer is mainly recharged from the occasional runoff water of the intermittent streams; its deposits belong to the Pleistocene and the recent. This aquifer is covering most of the wadi floor with alluvial deposits, which can be subdivided into two groups:

The first group is the wadi fillings in the depressions over alluvial fans and along alluvial courses. These sediments 


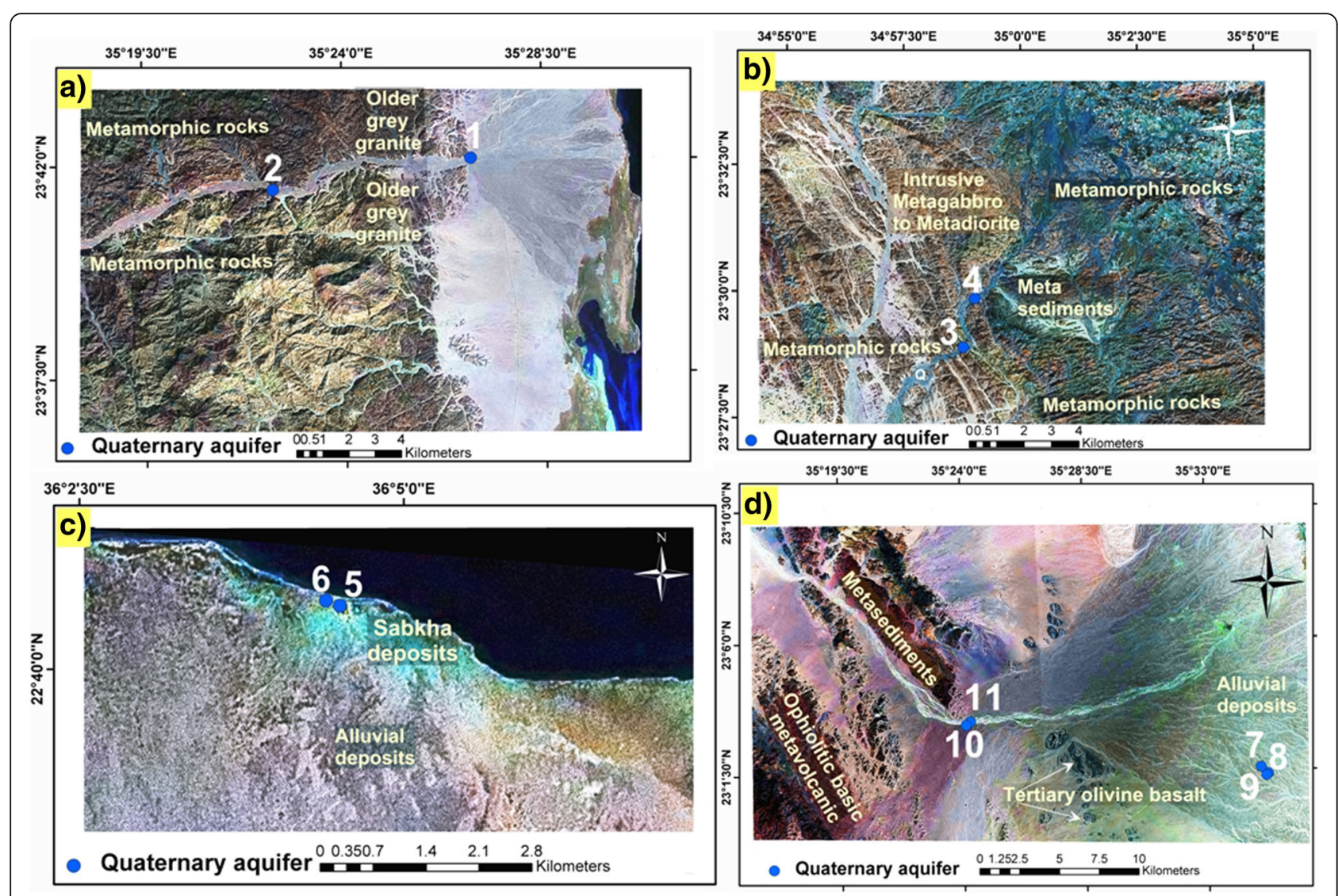

Fig. 4 Wells location map of alluvial Quaternary aquifer illustrated on Landsat images (GeoCover ETM+ 2010). a-d The geology along the flow path which affected the groundwater wells

have a variable thickness which occurred overlie sedimentary and basement rocks. The second group is coral and beach sand deposits where the alluvial sediments are of special hydrogeologic significance. It is covered by sand all over the area and sometimes by silt and gravel. The Quaternary aquifer is explored through 11 wells where the total depth ranges from 2 to $30 \mathrm{~m}$, and the depth to water is varying between 1.05 and $23.4 \mathrm{~m}$ (Table 1 ).

\section{Nubian Sandstone Aquifer of Upper Cretaceous ages}

The Nubian Sandstone Aquifer occupies mostly an area of Wadi Hodein Basin; in such rocks, faults and slight folding were associated with the Red Sea Rifting blocks. These blocks act as independent aquifers, which flowing naturally in the form of springs (six springs) with the discharge rates up to $21 \mathrm{~m}^{3} / \mathrm{h}$. Most of the groundwater of the Nubian Sandstone is slightly fresh. The aquifer consists of sandstone which is fine to coarse-grained with clay and siltstone intercalation (Fig. 5). On the other hand, six wells were drilled penetrating the Nubian Sandstone Aquifer up to $310 \mathrm{~m}$, while the depth to water ranges between 24.5 and $28 \mathrm{~m}$. The hydrologic parameters of this aquifer were deduced from pumping tests carried out by Elewa (2000). He stated that the transmissivity ranges from 2.72 to $72.4 \mathrm{~m}^{2} /$ day, and the recharge processes are mainly due to the direct infiltration from rainfall and partly from surface runoff through the fractured sandstone. This is confirmed through continuous discharge from the springs (since 1868).

\section{Fractured basement rock of Precambrian age}

This aquifer comprises the fractured Precambrian basement which represents a part of the Red Sea mountainous area. These rocks include granites (old and young), granitoides, gneisses, migmatites, schists, metasediments, diorites, and quartzites. These rocks are characterized by high and dense fractures, and faults intersecting with each other facilitate the recharge process. This structural setting provides chances for groundwater to be accumulated and moved through the fracture systems. The occurrence of groundwater depends mainly upon the depth, width, and extension of fractures, where the water quantity is frequently limited but provides a water supply for the local population. The aquifer is penetrated through 14 hand-dug wells (Fig. 6) where the total depth ranges between 3.5 and $33 \mathrm{~m}$ while the depth to water varies between 1.4 and $29.5 \mathrm{~m}$ (Table 1). 


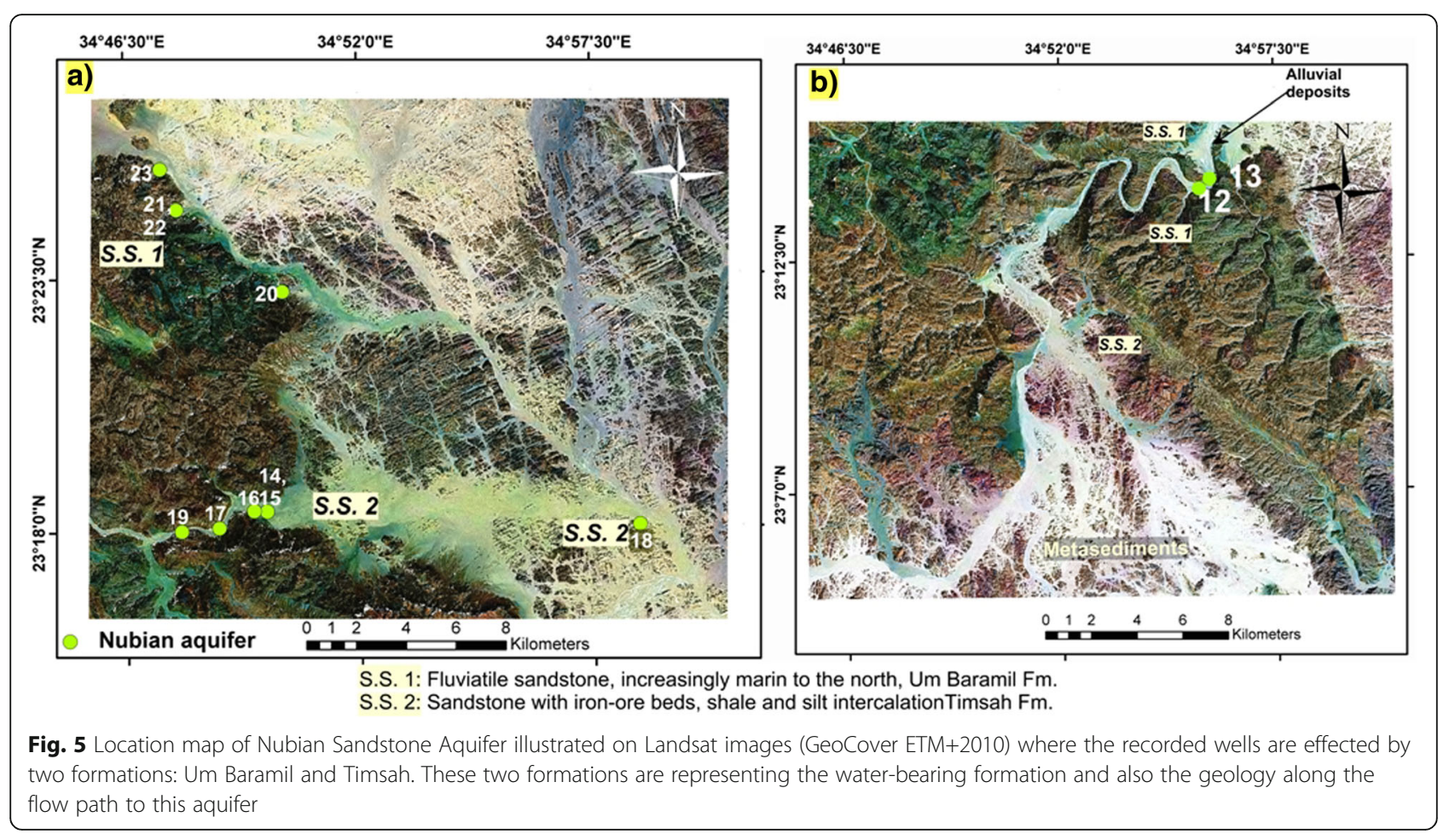

\section{Chemistry of groundwater}

The data of analyses of the groundwater wells are shown both in Tables 2 and 3. The groundwater salinity in the study area ranged from fresh to brackish and saline. The lowest total dissolved salt (TDS) value (311 mg/l) was recorded in well no. 21 of the Nubian Sandstone Aquifer, while the highest value was obtained from well no. 28 of the fractured basement aquifer. The alluvial aquifer showed variation in the salinity values that ranged between 1253 and 18,854 mg/l. The majority of groundwater samples of this aquifer have one order of ion dominance: $\mathrm{Na}>\mathrm{Ca}>\mathrm{Mg}$ with $\mathrm{Cl}>\mathrm{SO}_{4}>\mathrm{HCO}_{3}$. The analyses of groundwater belonging to the Nubian Sandstone Aquifer reveal relative symmetry in their chemical composition. All groundwater samples were freshwater (except one sample of well no. 13, with TDS of $14,388 \mathrm{mg} / \mathrm{l})$. The TDS values ranged between 311 and $943 \mathrm{mg} / \mathrm{l}$. The ion dominance of this aquifer includes two groups: $\mathrm{Na}>\mathrm{Ca}>\mathrm{Mg}$ with $\mathrm{Cl}>\mathrm{HCO}_{3}>\mathrm{SO}_{4}$ which was recorded in the most of groundwater samples and $\mathrm{Na}>\mathrm{Mg}>\mathrm{Ca}$ with $\mathrm{Cl}>\mathrm{SO}_{4}>\mathrm{HCO}_{3}$ in few wells.

On the other hand, the chemical results of the groundwater samples tapped from the fractured basement aquifer showed that a wide range of salinity and the water samples can be classified from fresh to brackish, and only two wells were classified as saline (well nos. 28 and 37). According to the values of TDS, it had a wide range; it ranged from 330 to $19,375 \mathrm{mg} / \mathrm{l}$. Three groups of ion dominance were observed: $\mathrm{Na}>\mathrm{Ca}>\mathrm{Mg}$ with $\mathrm{Cl}>\mathrm{SO}_{4}>$ $\mathrm{HCO}_{3}$ which was noted in the most samples, $\mathrm{Na}>\mathrm{Mg}>$
$\mathrm{Ca}$ with $\mathrm{Cl}>\mathrm{SO}_{4}>\mathrm{HCO}_{3}$ which was recorded in three groundwater samples, and finally a group that was characterized by the freshwater where bicarbonates are greater than sulfates $\mathrm{HCO}_{3}>\mathrm{Cl}>\mathrm{SO}_{4}$ with cation dominance varies between $\mathrm{Na}>\mathrm{Mg}>\mathrm{Ca}$ and $\mathrm{Ca}>\mathrm{Mg}$.

The excess of $\mathrm{Cl}^{-}$and $\mathrm{Na}^{+}$can be explained by the combined effect of the unfractionated aerosols belonging to marine environment and dissolution of watershed rocks. The marine aerosols are most likely a dominant source of solutes where marine aerosols may be deposited as dry salts on the land surface and periodically dissolved and transported downward towards the aquifer during sporadic rainfall events. Some of these solutes may show high concentration through evaporation processes (such as, halite, gypsum, and other salts) where these salts may be accumulated for many years and then transported to the underground aquifer when a significant rainfall event occurs. On the other hand, the alkaline earth elements may be derived by dissolution of silicate minerals (e.g., plagioclase feldspar, chlorite, or biotite), carbonates (dolomite or calcite), gypsum, and/or cation exchange of $\mathrm{Na}^{+}$for $\mathrm{Ca}^{2+}$, and $\mathrm{Mg}^{2+}$ on clay minerals. The excess of $\mathrm{Ca}^{2+}$ and $\mathrm{Mg}^{2+}$ does not result from the dissolution of carbonate rocks (calcite, dolomite) where the distribution is limited. Therefore, it can be attributed to metavolcanic and basic rocks.

Trace concentrations for 15 elements of the studied groundwater samples are generally between 0.0001 and $22.82 \mathrm{mg} / \mathrm{l}$ (Table 3). Concentrations of Fe are $\mathrm{Mn}$ are relatively low in the studied groundwater except for the 

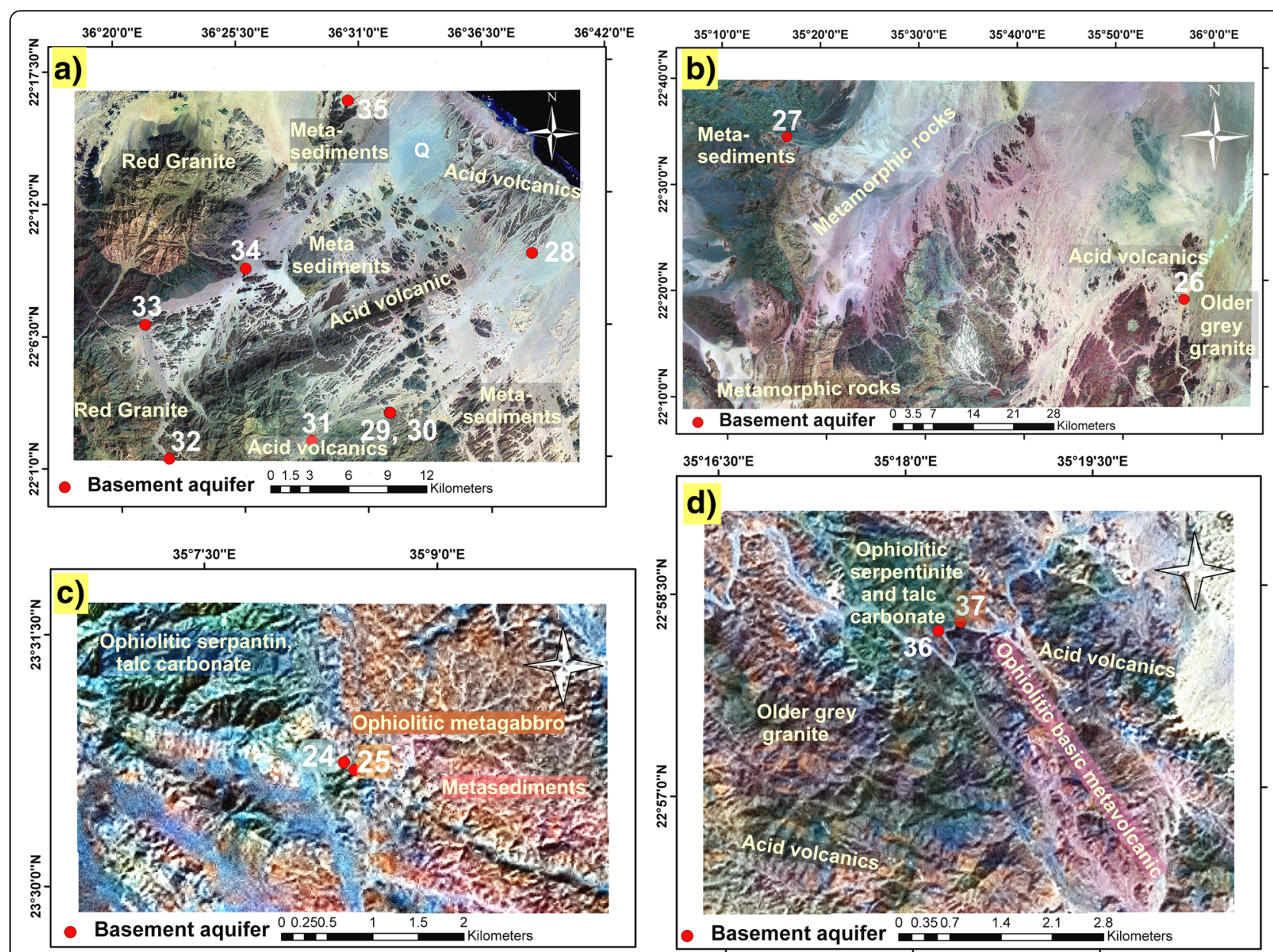

Fig. 6 Wells' location map of the fractured basement aquifer illustrated on Landsat images (GeoCover ETM+2010) showing the diversity of rocks in the vicinities of groundwater wells

water from Nubian Sandstone Aquifer that showed a noticeable increase and ranging between 0.08 and $10.49 \mathrm{mg} / \mathrm{l}$ for Fe and between 0.02 and $2.83 \mathrm{mg} / \mathrm{l}$ for $\mathrm{Mn}$. This is due to the lithologic nature of Nubian sandstones which are rich in iron and manganese oxides. On the other hand, $\mathrm{Sr}$ and $\mathrm{Al}$ show notable recordings in the three aquifers where higher concentrations are present in the alluvial aquifer $(19.5 \mathrm{mg} / \mathrm{l}, 20.46 \mathrm{mg} / \mathrm{l}$, and $22.8 \mathrm{mg} / \mathrm{l}$ for $\mathrm{Sr}$ and $6.67 \mathrm{mg} / \mathrm{l}$ for Al). This is due to the presence of $\mathrm{Sr}$ and $\mathrm{Al}$ sources which are found both in the water-bearing rocks and also along the surface water path that recharges the groundwater. These sources are represented in the basement rocks, sandstone sediments, and carbonate rocks. Other trace elements did not show any constant trend as a result of a great diversity in the rocky nature for each of aquifers and watersheds.

\section{Hypothetical salts of groundwater}

Regarding the hypothetical salt combinations in the three investigated aquifers of the studied area, there are six main assemblages detected in the groundwater that are summarized in (Table 4). Generally, it is obvious that the groundwater samples of the study area are characterized by five different assemblages (II-VI); this indicates that there is no connection between them and affected by different conditions. The groundwater samples of the alluvial aquifer possessed three of the hypothetical salts assemblages, from IV to VI. Also, the groundwater samples of both the Nubian Sandstone and the fractured basement aquifers are characterized by three hypothetical salts assemblages II, III, and V for the Nubian Sandstone and III, IV, and VI for the fractured basement aquifer. Generally, the groundwater is characterized by meteoric water origin which is affected by leaching and dissolution processes. The presence of $\mathrm{Na}_{2} \mathrm{SO}_{4}, \mathrm{MgSO}_{4}$, and $\mathrm{Mg}\left(\mathrm{HCO}_{3}\right)_{2}$ salts reflects the effect of dissolution with leaching processes of earthly salts as the groundwater is characterized by assemblage II. The groundwater that is characterized by assemblages (III, IV, V and VI) that contain $\mathrm{MgCl}_{2}$ salt means that this groundwater 
Table 2 Chemical data (major elements) of the investigated groundwater samples

\begin{tabular}{|c|c|c|c|c|c|c|c|c|c|c|c|c|c|c|}
\hline \multirow[t]{2}{*}{ Well no. } & \multirow[t]{2}{*}{ Aquifer } & \multirow[t]{2}{*}{ Eh } & \multirow[t]{2}{*}{$\mathrm{pH}$} & \multirow{2}{*}{$\begin{array}{l}\text { EC } \\
(\mu S / \mathrm{cm})\end{array}$} & \multirow{2}{*}{$\begin{array}{l}\text { TDS } \\
(\mathrm{mg} / \mathrm{l})\end{array}$} & \multicolumn{4}{|c|}{ Cation (mg/l) } & \multicolumn{4}{|c|}{ Anion (mg/l) } & \multirow[t]{2}{*}{ SAR } \\
\hline & & & & & & $\overline{\mathrm{Ca}^{2+}}$ & $\mathrm{Mg}^{2+}$ & $\mathrm{Na}^{+}$ & $\mathrm{K}^{+}$ & $\overline{\mathrm{CO}_{3}^{2-}}$ & $\mathrm{HCO}_{3}^{-}$ & $\mathrm{SO}_{4}{ }^{2-}$ & $\mathrm{Cl}^{-}$ & \\
\hline 1 & \multirow[t]{11}{*}{ Alluvial } & 127 & 7.7 & 4200 & 2427 & 196.30 & 111.6 & 500 & 7 & 0.00 & 137.25 & 464.06 & 1079.4 & 7 \\
\hline 2 & & 129 & 7.6 & 3970 & 2153 & 242.60 & 108.0 & 360 & 6 & 0.00 & 134.20 & 469.5 & 899.50 & 4.8 \\
\hline 3 & & 82 & 8.4 & 3420 & 2068 & 135.63 & 100.6 & 410 & 14 & 30.00 & 219.60 & 780 & 488.30 & 6.5 \\
\hline 4 & & 81 & 8.4 & 2408 & 1253 & 58.56 & 114.0 & 210 & 13 & 30.00 & 259.25 & 388.92 & 308.40 & 3.6 \\
\hline 5 & & 104 & 7.6 & 13,810 & 8386 & 654.40 & 318.4 & 1850 & 20 & 15.00 & 79.30 & 2044.65 & 3443.8 & 14 \\
\hline 6 & & 107 & 7.9 & 16,410 & 9750 & 703.60 & 390.9 & 2200 & 17 & 15.00 & 122.00 & 1942.35 & 4420.4 & 16.5 \\
\hline 7 & & 119 & 7.4 & 19,940 & 11,053 & 1280.0 & 555.7 & 2000 & 16 & 0.00 & 54.90 & 800 & 6373.6 & 11.7 \\
\hline 8 & & 124 & 7.6 & 33,100 & 18,854 & 2117.0 & 778.8 & 3700 & 31 & 0.00 & 61.00 & 1274 & 10,922 & 17.4 \\
\hline 9 & & 119 & 7.4 & 17,320 & 10,095 & 1375.0 & 373.2 & 1750 & 20 & 0.00 & 45.75 & 900 & 5654 & 10.8 \\
\hline 10 & & 100 & 7.4 & 13,340 & 7880 & 1075.0 & 190.3 & 1400 & 16 & 0.00 & 67.10 & 1567.6 & 3598 & 10.3 \\
\hline 11 & & 90 & 7.5 & 11,550 & 6446 & 1100.0 & 127.7 & 1050 & 17 & 0.00 & 45.75 & 633.05 & 3495 & 8 \\
\hline 12 & \multirow{12}{*}{$\begin{array}{l}\text { Nubian } \\
\text { Sandstone }\end{array}$} & 130 & 7.8 & 1394 & 776 & 80.69 & 40.46 & 125 & 10 & 0.00 & 167.75 & 198.47 & 237.47 & 2.8 \\
\hline 13 & & 145 & 7.3 & 25,350 & 14,388 & 562.90 & 727.3 & 3700 & 36 & 15.00 & 207.40 & 1841.9 & 7401 & 24 \\
\hline 14 & & 94 & 8.5 & 1621 & 757 & 15.63 & 11.69 & 245 & 7 & 0.00 & 85.40 & 64.72 & 370 & 11.5 \\
\hline 15 & & 97 & 8.1 & 1653 & 778 & 21.39 & 36.09 & 200 & 9 & 0.00 & 115.90 & 155.45 & 298.12 & 6 \\
\hline 16 & & 98 & 8 & 2045 & 915 & 27.80 & 47.46 & 230 & 11 & 15.00 & 152.50 & 178.31 & 328.96 & 6 \\
\hline 17 & & 96 & 7.9 & 2186 & 943 & 28.00 & 58.39 & 230 & 11 & 15.00 & 146.40 & 146 & 380.36 & 5.6 \\
\hline 18 & & 93 & 7.4 & 703 & 341 & 59.00 & 20.03 & 32 & 6 & 0.00 & 122.00 & 52 & 110.51 & 1.1 \\
\hline 19 & & 96 & 7.2 & 862 & 425 & 76.56 & 22.79 & 40 & 9 & 0.00 & 158.60 & 61.192 & 136.21 & 1.1 \\
\hline 20 & & 93 & 8.3 & 723 & 356 & 42.46 & 26.99 & 40 & 12 & 15.00 & 158.60 & 53.152 & 87.38 & 1.18 \\
\hline 21 & & 96 & 8 & 655 & 311 & 49.76 & 20.11 & 32 & 7 & 15.00 & 122.00 & 37.884 & 88.67 & 1.1 \\
\hline 22 & & 88 & 7.9 & 696 & 346 & 58.32 & 20.84 & 32 & 6 & 15.00 & 122.00 & 50.196 & 102.80 & 1.1 \\
\hline 23 & & 94 & 7.2 & 1003 & 579 & 99.43 & 25.03 & 65 & 7 & 0.00 & 167.75 & 144.615 & 154.20 & 1.51 \\
\hline 24 & \multirow{17}{*}{$\begin{array}{l}\text { Fractured } \\
\text { basement }\end{array}$} & 80 & 8.3 & 685 & 320 & 13.95 & 47.80 & 36 & 5 & 15.00 & 170.80 & 30.3 & 86.10 & 1.04 \\
\hline 25 & & 82 & 8.5 & 768 & 353 & 13.85 & 50.31 & 44 & 7 & 15.00 & 183.00 & 28.636 & 102.80 & 1.23 \\
\hline 26 & & 90 & 8.1 & 5280 & 3522 & 140.10 & 82.84 & 620 & 4 & 15.00 & 122.00 & 1751.34 & 848.10 & 10 \\
\hline 27 & & 75 & 8.2 & 862 & 502 & 15.91 & 68.50 & 55 & 3 & 15.00 & 122.00 & 178.4 & 105.37 & 1.33 \\
\hline 28 & & 133 & 6.7 & 35,800 & 19,375 & 3839.0 & 477.2 & 2450 & 25 & 0.00 & 39.65 & 228.12 & 12,336 & 9.9 \\
\hline 29 & & 66 & 8.1 & 1837 & 817 & 45.69 & 19.34 & 230 & 2 & 18.00 & 195.20 & 105.94 & 298.12 & 7.19 \\
\hline 30 & & 68 & 8.1 & 2068 & 1139 & 63.72 & 20.34 & 320 & 3 & 15.00 & 207.40 & 243.1 & 370.08 & 8.94 \\
\hline 31 & & 80 & 7.8 & 1931 & 1027 & 159.80 & 40.53 & 160 & 3 & 15.00 & 213.50 & 120 & 421.48 & 2.93 \\
\hline 32 & & 97 & 7.4 & 7240 & 4289 & 621.00 & 178.3 & 620 & 2 & 15.00 & 106.75 & 1000 & 1799 & 5.62 \\
\hline 33 & & 85 & 7.4 & 3900 & 2079 & 294.60 & 82.86 & 320 & 2 & 18.00 & 131.15 & 396.9 & 899.50 & 4.24 \\
\hline 34 & & 93 & 7.2 & 8290 & 4986 & 678.00 & 194.1 & 750 & 3 & 0.00 & 106.75 & 1200 & 2107 & 6.5 \\
\hline 35 & & 94 & 7.3 & 10,500 & 6151 & 737.50 & 171.1 & 1100 & 10 & 15.00 & 134.20 & 1994.15 & 2056 & 9.4 \\
\hline 36 & & 85 & 7.8 & 9210 & 5138 & 487.90 & 164.9 & 1100 & 16 & 6.00 & 97.60 & 1103.75 & 2210 & 11 \\
\hline 37 & & 96 & 7.6 & 23,340 & 13,673 & 1200.0 & 503.0 & 2800 & 20 & 0.00 & 122.00 & 3331.9 & 5756.8 & 17 \\
\hline Rainfall & & - & 7.0 & 125 & 80 & 10.80 & 3.01 & 15 & 2 & 0.00 & 49.00 & 10 & 15.00 & 1.00 \\
\hline Sea water & & 124 & 8 & 66,400 & 38,021 & 721.20 & 1668 & 11,000 & 330 & 21.00 & 64.05 & 1761.5 & 22,487 & 51.4 \\
\hline P.L & & & $6.5-8.5$ & & 1000 & 200 & 150 & 200 & - & - & - & 250 & 500 & \\
\hline
\end{tabular}


Table 3 Minor and trace elements concentration (in $\mathrm{mg} / \mathrm{l}$ ) of the investigated groundwater samples

\begin{tabular}{|c|c|c|c|c|c|c|c|c|c|c|c|c|c|c|c|c|}
\hline Well no. & Aquifer & $\mathrm{Al}$ & B & $\mathrm{Ba}$ & $\mathrm{Cr}$ & $\mathrm{Cu}$ & $\mathrm{Fe}$ & $\mathrm{Mn}$ & Mo & $\mathrm{Ni}$ & $\mathrm{Pb}$ & $\mathrm{Sr}$ & $\mathrm{Ti}$ & V & $\mathrm{Zn}$ & $\mathrm{P}$ \\
\hline 1 & \multirow[t]{11}{*}{ Alluvial } & 0.017 & 0.716 & 0.024 & 0.019 & 0.000 & 0.034 & 0.013 & 0.035 & 0.003 & 0.054 & 3.944 & 0.049 & 0.048 & 0.017 & 0.050 \\
\hline 2 & & 6.767 & 0.626 & 0.123 & 0.013 & 0.016 & 3.940 & 0.417 & 0.007 & 0.028 & 0.065 & 3.819 & 0.050 & 0.027 & 0.064 & 0.582 \\
\hline 3 & & 0.119 & 1.090 & 0.033 & 0.013 & 0.000 & 0.040 & 0.006 & 0.023 & 0.006 & 0.018 & 0.990 & 0.008 & 0.023 & 0.000 & 0.008 \\
\hline 4 & & 0.000 & 0.675 & 0.045 & 0.008 & 0.000 & 0.000 & 0.000 & 0.034 & 0.002 & 0.015 & 1.022 & 0.002 & 0.043 & 0.000 & 0.039 \\
\hline 5 & & 0.108 & 2.607 & 0.028 & 0.021 & 0.000 & 0.109 & 0.011 & 0.056 & 0.006 & 0.008 & 9.823 & 0.032 & 0.022 & 0.012 & 0.113 \\
\hline 6 & & 0.107 & 3.069 & 0.033 & 0.014 & 0.004 & 0.099 & 0.013 & 0.048 & 0.006 & 0.008 & 10.840 & 0.027 & 0.027 & 0.003 & 0.217 \\
\hline 7 & & 0.785 & 2.574 & 0.051 & 0.017 & 0.011 & 1.541 & 0.066 & 0.006 & 0.009 & 0.002 & 20.460 & 0.058 & 0.017 & 0.223 & 0.037 \\
\hline 8 & & 0.477 & 3.231 & 0.067 & 0.030 & 0.000 & 0.739 & 0.019 & 0.007 & 0.008 & 0.003 & 22.820 & 0.065 & 0.026 & 0.033 & 0.018 \\
\hline 9 & & 0.269 & 1.807 & 0.036 & 0.020 & 0.000 & 0.479 & 0.023 & 0.006 & 0.007 & 0.010 & 19.560 & 0.049 & 0.029 & 0.043 & 0.018 \\
\hline 10 & & 0.032 & 0.779 & 0.021 & 0.009 & 0.001 & 0.000 & 0.224 & 0.005 & 0.005 & 0.000 & 13.190 & 0.028 & 0.015 & 0.000 & 0.004 \\
\hline 11 & & 0.035 & 0.949 & 0.032 & 0.013 & 0.000 & 0.000 & 0.094 & 0.017 & 0.006 & 0.004 & 15.610 & 0.032 & 0.023 & 0.009 & 0.000 \\
\hline 12 & \multirow{12}{*}{$\begin{array}{l}\text { Nubian } \\
\text { Sandstone }\end{array}$} & 0.000 & 0.161 & 0.039 & 0.023 & 0.396 & 1.680 & 1.255 & 0.000 & 0.006 & 0.022 & 0.934 & 0.014 & 0.000 & 0.261 & 0.004 \\
\hline 13 & & 1.213 & 2.716 & 0.021 & 0.011 & 0.002 & 10.490 & 2.831 & 0.000 & 0.015 & 0.020 & 16.040 & 0.087 & 0.000 & 9.551 & 0.040 \\
\hline 14 & & 0.180 & 0.073 & 0.070 & 0.024 & 0.000 & 1.405 & 0.052 & 0.000 & 0.002 & 0.030 & 0.663 & 0.000 & 0.000 & 3.067 & 0.055 \\
\hline 15 & & 0.249 & 0.099 & 0.030 & 0.012 & 0.007 & 4.289 & 0.215 & 0.000 & 0.002 & 0.046 & 0.234 & 0.002 & 0.004 & 1.915 & 0.062 \\
\hline 16 & & 0.043 & 0.134 & 0.016 & 0.017 & 0.002 & 4.153 & 0.197 & 0.000 & 0.002 & 0.026 & 0.412 & 0.000 & 0.000 & 1.162 & 0.018 \\
\hline 17 & & 0.045 & 0.149 & 0.028 & 0.016 & 0.001 & 0.246 & 0.009 & 0.000 & 0.006 & 0.015 & 1.302 & 0.015 & 0.004 & 0.078 & 0.060 \\
\hline 18 & & 0.000 & 0.000 & 0.047 & 0.026 & 0.000 & 0.635 & 0.540 & 0.000 & 0.004 & 0.010 & 0.363 & 0.008 & 0.000 & 0.011 & 0.000 \\
\hline 19 & & 0.045 & 0.000 & 0.112 & 0.004 & 0.000 & 0.366 & 1.662 & 0.000 & 0.003 & 0.011 & 0.453 & 0.017 & 0.000 & 0.013 & 0.153 \\
\hline 20 & & 0.040 & 0.000 & 0.064 & 0.013 & 0.000 & 0.366 & 0.024 & 0.004 & 0.000 & 0.011 & 0.381 & 0.004 & 0.000 & 0.000 & 0.000 \\
\hline 21 & & 0.044 & 0.000 & 0.070 & 0.004 & 0.007 & 0.108 & 0.045 & 0.000 & 0.000 & 0.010 & 0.312 & 0.010 & 0.000 & 0.002 & 0.000 \\
\hline 22 & & 0.079 & 0.000 & 0.017 & 0.016 & 0.000 & 0.083 & 0.090 & 0.000 & 0.001 & 0.010 & 0.385 & 0.016 & 0.000 & 0.007 & 0.024 \\
\hline 23 & & 0.040 & 0.000 & 0.068 & 0.012 & 0.000 & 0.137 & 0.143 & 0.000 & 0.002 & 0.010 & 0.584 & 0.016 & 0.000 & 0.006 & 0.207 \\
\hline 24 & \multirow{15}{*}{$\begin{array}{l}\text { Fractured } \\
\text { basement }\end{array}$} & 0.000 & 0.338 & 0.006 & 0.001 & 0.000 & 0.017 & 0.008 & 0.008 & 0.001 & 0.010 & 0.172 & 0.000 & 0.007 & 0.000 & 0.000 \\
\hline 25 & & 0.058 & 0.059 & 0.004 & 0.020 & 0.000 & 0.254 & 0.014 & 0.001 & 0.001 & 0.013 & 0.207 & 0.002 & 0.013 & 0.145 & 0.006 \\
\hline 26 & & 0.351 & 1.759 & 0.018 & 0.025 & 0.000 & 0.263 & 0.015 & 0.033 & 0.005 & 0.013 & 2.531 & 0.016 & 0.036 & 0.000 & 0.012 \\
\hline 27 & & 0.753 & 0.022 & 0.016 & 0.032 & 0.000 & 1.129 & 0.054 & 0.003 & 0.054 & 0.013 & 0.251 & 0.002 & 0.009 & 0.095 & 0.075 \\
\hline 28 & & 0.265 & 5.423 & 0.101 & 0.009 & 0.007 & 1.257 & 0.063 & 0.003 & 0.007 & 0.005 & 5.140 & 0.061 & 0.022 & 0.071 & 0.255 \\
\hline 29 & & 0.107 & 0.651 & 0.053 & 0.018 & 0.000 & 0.056 & 0.103 & 0.010 & 0.003 & 0.015 & 0.695 & 0.003 & 0.028 & 0.000 & 0.026 \\
\hline 30 & & 0.165 & 1.054 & 0.037 & 0.024 & 0.000 & 0.197 & 0.112 & 0.007 & 0.003 & 0.012 & 0.796 & 0.005 & 0.018 & 0.018 & 0.213 \\
\hline 31 & & 0.086 & 0.386 & 0.062 & 0.009 & 0.000 & 0.016 & 0.031 & 0.006 & 0.002 & 0.013 & 1.461 & 0.012 & 0.015 & 0.000 & 0.037 \\
\hline 32 & & 0.062 & 0.763 & 0.036 & 0.009 & 0.000 & 0.000 & 0.006 & 0.040 & 0.004 & 0.009 & 5.514 & 0.028 & 0.013 & 0.000 & 0.000 \\
\hline 33 & & 0.085 & 0.552 & 0.104 & 0.000 & 0.000 & 0.000 & 0.867 & 0.014 & 0.003 & 0.013 & 2.703 & 0.021 & 0.000 & 0.000 & 0.008 \\
\hline 34 & & 1.246 & 0.755 & 0.070 & 0.005 & 0.003 & 0.619 & 0.208 & 0.001 & 0.007 & 0.005 & 6.687 & 0.034 & 0.012 & 0.011 & 0.191 \\
\hline 35 & & 0.023 & 2.858 & 0.024 & 0.020 & 0.000 & 0.000 & 0.000 & 0.006 & 0.005 & 0.007 & 11.110 & 0.024 & 0.000 & 0.000 & 0.006 \\
\hline 36 & & 0.072 & 0.631 & 0.046 & 0.007 & 0.000 & 0.000 & 0.001 & 0.002 & 0.005 & 0.004 & 5.475 & 0.022 & 0.016 & 0.004 & 0.031 \\
\hline 37 & & 0.019 & 1.616 & 0.051 & 0.004 & 0.001 & 0.000 & 0.017 & 0.001 & 0.006 & 0.005 & 10.210 & 0.022 & 0.019 & 0.000 & 0.079 \\
\hline Sea water & & 0.967 & 6.536 & 0.012 & 0.012 & 0.003 & 0.431 & 0.063 & 0.007 & 0.005 & 0.000 & 9.741 & 0.032 & 0.000 & 0.009 & 0.047 \\
\hline \multicolumn{2}{|c|}{$\begin{array}{l}\text { Permissible limit } \\
\text { (EHCW 2007) }\end{array}$} & 0.2 & 1 & 1 & 0.05 & 1 & 0.3 & 0.05 & 0.07 & 0.02 & 0.05 & - & - & - & 3 & - \\
\hline
\end{tabular}

has a meteoric origin and affected by leaching and dissolution of marine or sabkha deposits as most of the groundwater samples of the alluvial, the Nubian Sandstone, and the fractured basement aquifers.

\section{Rocks geochemistry}

Based on field and Landsat investigations as well as to previous geochemical rock analyses, the geochemistry of both the water-bearing formation and the rocks 
Table 4 Groups of hypothetical salts for the studied groundwater samples

\begin{tabular}{|c|c|c|c|}
\hline \multirow[t]{2}{*}{ Aquifer } & \multicolumn{2}{|l|}{ Hypothetical salts } & \multirow[t]{2}{*}{ Well numbers } \\
\hline & Salts & Groups & \\
\hline \multirow[t]{3}{*}{ Alluvial } & $\mathrm{NaCl}, \mathrm{Na}_{2} \mathrm{SO}_{4}, \mathrm{MgSO}_{4}, \mathrm{CaSO}_{4}, \mathrm{Ca}\left(\mathrm{HCO}_{3}\right)_{2}$ & IV & 3,4 \\
\hline & $\mathrm{NaCl}, \mathrm{MgCl}_{2}, \mathrm{MgSO}_{4}, \mathrm{CaSO}_{4}, \mathrm{Ca}\left(\mathrm{HCO}_{3}\right)_{2}$ & V & $1,5,6$ \\
\hline & $\mathrm{NaCl}, \mathrm{MgCl}_{2}, \mathrm{CaCl}_{2}, \mathrm{CaSO}_{4}, \mathrm{Ca}\left(\mathrm{HCO}_{3}\right)_{2}$ & $\mathrm{Vl}$ & $2,7,8,9,10,11$ \\
\hline \multirow[t]{3}{*}{ Nubian Sandstone } & $\mathrm{NaCl}, \mathrm{Na}_{2} \mathrm{SO}_{4}, \mathrm{MgSO}_{4}, \mathrm{Mg}\left(\mathrm{HCO}_{3}\right)_{2}, \mathrm{Ca}\left(\mathrm{HCO}_{3}\right)_{2}$ & $\|$ & $14,15,16$ \\
\hline & $\mathrm{NaCl}, \mathrm{MgCl}_{2}, \mathrm{MgSO}_{4}, \mathrm{Mg}\left(\mathrm{HCO}_{3}\right)_{2}, \mathrm{Ca}\left(\mathrm{HCO}_{3}\right)_{2}$ & III & 17,20 \\
\hline & $\mathrm{NaCl}, \mathrm{MgCl}_{2}, \mathrm{MgSO}_{4}, \mathrm{CaSO}_{4}, \mathrm{Ca}\left(\mathrm{HCO}_{3}\right)_{2}$ & V & $12,13,18,19,21,22,23$ \\
\hline \multirow[t]{3}{*}{ Fractured basement } & $\mathrm{NaCl}, \mathrm{MgCl}_{2}, \mathrm{MgSO}_{4}, \mathrm{Mg}\left(\mathrm{HCO}_{3}\right)_{2}, \mathrm{Ca}\left(\mathrm{HCO}_{3}\right)_{2}$ & III & 24,25 \\
\hline & $\mathrm{NaCl}, \mathrm{Na}_{2} \mathrm{SO}_{4}, \mathrm{MgSO}_{4}, \mathrm{CaSO}_{4}, \mathrm{Ca}\left(\mathrm{HCO}_{3}\right)_{2}$ & IV & $26,29,30$ \\
\hline & $\mathrm{NaCl}, \mathrm{MgCl}_{2}, \mathrm{CaCl}_{2}, \mathrm{CaSO}_{4}, \mathrm{Ca}\left(\mathrm{HCO}_{3}\right)_{2}$ & $\mathrm{Vl}$ & $27,28,31,32,33,34,35,36,37$ \\
\hline Rainfall & $\mathrm{NaCl}, \mathrm{Na}_{2} \mathrm{SO}_{4}, \mathrm{NaHCO}_{3}, \mathrm{Mg}\left(\mathrm{HCO}_{3}\right)_{2}, \mathrm{Ca}\left(\mathrm{HCO}_{3}\right)_{2}$ & । & $\mathrm{R}$ \\
\hline Sea water & $\mathrm{NaCl}, \mathrm{MgCl}_{2}, \mathrm{MgSO}_{4}, \mathrm{CaSO}_{4}, \mathrm{Ca}\left(\mathrm{HCO}_{3}\right)_{2}$ & V & $\mathrm{S}$ \\
\hline
\end{tabular}

along the water flow path to the wells were elucidated for each well (Table 5). In the current research, the Landsat image has provided more details about the geology which affects the recorded wells where each group of wells and in some cases each well have a different geologic setting. The details about geochemistry of rocks which interact directly with groundwater (water-bearing formation) and other rocks which interact with surface water and recharge the aquifers are concluded in (Table 5). The alluvial aquifer is composed of sand, mud, and basement rock fragments in gravel and sand sizes. The geology of watersheds along the path to the alluvial wells has the following great varieties: older gray granite (well no. 1, Fig. 4a), metamorphic rocks (gneiss, amphibolites, schist; well no. 2, Fig. 4a), metagabbro, metasediments (well nos. 3 and 4, Fig. 4b), clay, sand and evaporates (well nos. 5 and 6, Fig. 4c), metasediments, ophiolitic basic metavolcanics, and Tertiary olivine basalt (well nos. 7 to 11, Fig. 4d). The recorded wells and springs which are penetrating the Nubian Sandstone Aquifer show a homogeneity in the lithologic nature where both the water-bearing and watersheds composed of sandstone with iron-ore beds, shale, and silt intercalation and coarse to medium fluviatile sandstone (well nos. 12 to 23, Fig. 5a, b). The mineralogy of these ferruginous sandstone and ironstone includes goethite, magnetite, quartz, illite, halite, kaolinite, dolomite, and vesuvianite with abundant $\mathrm{SiO}_{2}$, $\mathrm{Fe}_{2} \mathrm{O}_{3}, \mathrm{Al}_{2} \mathrm{O}_{3}$, Cao, and $\mathrm{MgO}$. On the other hand, the basement aquifer was explored through 15 wells penetrated five water-bearing rocks as follows: ophiolitic metagabbro (well nos. 24 and 25, Fig. 6c), older gray granite (well no. 26, Fig. 6b), metasediments (well no. 27, Fig. 6b), acid volcanic (well nos. 28 to 35, Fig. 6a), and ophiolitic serpentinite with talc carbonate (well nos. 36 and 37, Fig. 6d), (Table 5).

\section{Thematic layers affecting groundwater}

The data obtained from the investigation of Landsat images and DEM analyses were used for the generation of the thematic layers which are affecting the groundwater occurrences and quality and are shown in Figs. 7, 8, 9, 10, 11, and 12.

\section{Structural lineaments}

The structural lineaments of the area under investigation were elucidated and stated this area was affected by sets of faults where the trends of lineaments are NE-SW, E-W, and some NW-SE which are parallel to the Red Sea Rift (Fig. 7). These lineaments are concentrated in the southern and western parts of the study area where Nubian sediments and basement rocks are located. The Nubian Sandstone is fractured to a lesser degree than the basement rocks; these fractures are playing the main role in both groundwater occurrences and its recharge. With the comparison between drainage networks layer (Fig. 10) and structural lineament layer (Fig. 7), it is assumed that drainage lines are structurally controlled and developed along faults and/or fractures.

\section{Elevation}

The elevation difference over the study area reaches about $1700 \mathrm{~m}$ which reveals a great variation in the terrain shape. The coastal plain shows the lower elevation areas as well as the areas along the drainage lines in between the Red Sea Mountains. These lowlands are representing the water collectors where the majority of surface water running and can enhance the groundwater recharge (Fig. 8), while the high lands represent the main watersheds which receive any rainfalls and directed to the lower-altitude areas.

\section{Drainage networks and hydrographic basins}

The hydrographic basins were extracted through DEM analyses where the area has about 16 main basins (Fig. 9). These basins were named according to topographic maps, 
Table 5 Geology and geochemistry of water bearing formation and watershed affecting groundwater wells

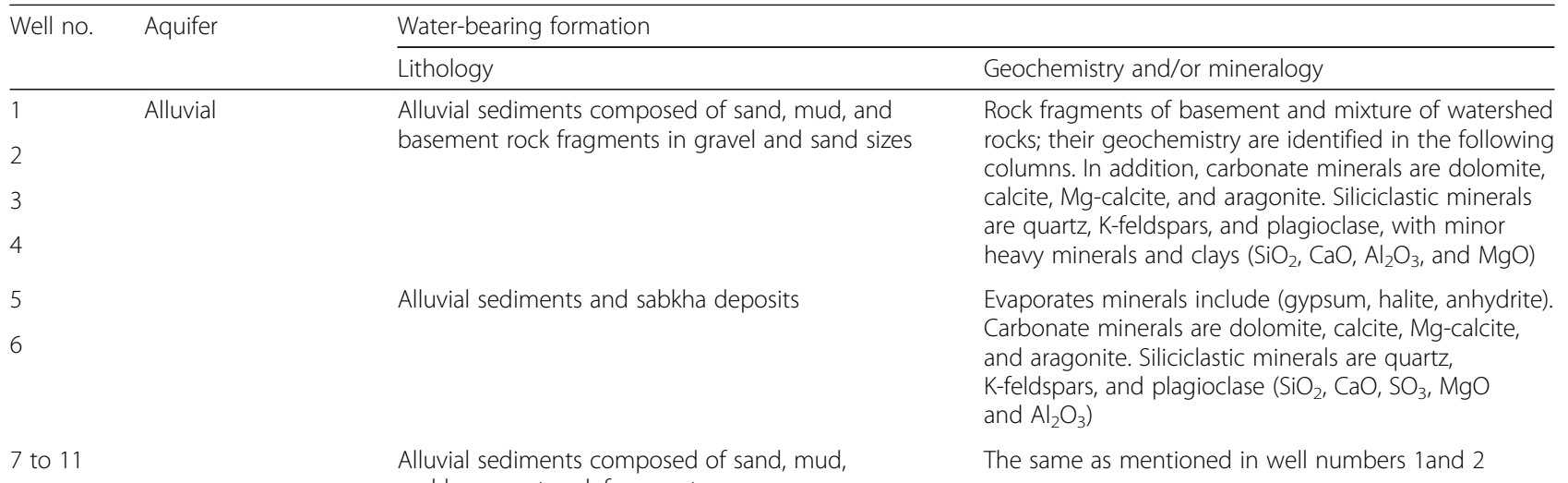

12 to 19 Nubian Sandstone Sandstone with iron-ore beds, shale, and silt intercalation

20 to 23

24

Fractured basement

Coarse to medium fluviatile sandstone

25

26

27

28 to 35

36

37

Well no. Aquifer

1 Alluvial

3

4

5

7 to 11

12 to $23 \quad$ Nubian Sandstone

Sandstone with iron-ore beds, shale, and silt intercalation

Older gray granite

Metasediments

Acid volcanics

Ophiolitic serpentinite and talc carbonate Lithology

Older gray granite

Metamorphic rocks

Metagabbro, metasediments Tertiary olivine basalt
Ferruginous sandstone and ironstone. The mineralogy includes goethite magnetite, quartz, illite, halite, kaolinite, dolomite, and vesuvianite. Abundant $\mathrm{SiO}_{2}$, $\mathrm{Fe}_{2} \mathrm{O}_{3}, \mathrm{Al}_{2} \mathrm{O}_{3}, \mathrm{CaO}$, and $\mathrm{MgO}$

$\mathrm{SiO}_{2}, \mathrm{Al}_{2} \mathrm{O}_{3}, \mathrm{CaO}, \mathrm{Fe}_{2} \mathrm{O}_{3}, \mathrm{MgO}, \mathrm{Na}_{2} \mathrm{O}$

The geology along the water flow path to the wells

Sabkha deposits included clay, sand, and evaporates

Metasediments, ophiolitic basic metavolcanics,
High $\mathrm{SiO}_{2}, \mathrm{TiO}_{2}, \mathrm{CaO}, \mathrm{NaO}_{2}$, and $\mathrm{P}_{2} \mathrm{O}_{5}$ and low $\mathrm{K}_{2} \mathrm{O}$ and $\mathrm{FeO}$, with abundant trace elements of $\mathrm{Ba}$ and $\mathrm{Rb}$

Abubdant $\mathrm{SiO}_{2}, \mathrm{Al}_{2} \mathrm{O}_{3}, \mathrm{CaO}, \mathrm{Fe}_{2} \mathrm{O}_{3}, \mathrm{MgO}, \mathrm{Na}_{2} \mathrm{O}$

Include rhyolite, rhyodacite, and dacite. High concentrations of $\mathrm{SiO}_{2}, \mathrm{Na}_{2} \mathrm{O}, \mathrm{Fe}_{2} \mathrm{O}_{3}, \mathrm{~K} 2 \mathrm{O}, \mathrm{Zr}, \mathrm{Nb}$, and $\mathrm{Y}$ but low in $\mathrm{MgO}, \mathrm{CaO}, \mathrm{Cr}, \mathrm{Ni}, \mathrm{Sr}, \mathrm{Ga}$, and $\mathrm{V}$

Include magnizite, chromite, dolomite, talc, iron oxides (geothite, hematite, magnitite). Abundant $\mathrm{Al}_{2} \mathrm{O}_{3}, \mathrm{SiO}_{2}$, $\mathrm{FeO}, \mathrm{TiO}_{2}, \mathrm{CaMg}\left(\mathrm{CO}_{3}\right)_{2}, \mathrm{CaCO}_{3}$, and Fe-Ti oxides

Geochemistry and/or mineralogy

High $\mathrm{SiO}_{2}, \mathrm{TiO}_{2}, \mathrm{CaO}, \mathrm{NaO}_{2}$, and $\mathrm{P}_{2} \mathrm{O}_{5}$ and low $\mathrm{K}_{2} \mathrm{O}$ and $\mathrm{FeO}$, with abundant trace elements of $\mathrm{Ba}$ and $\mathrm{Rb}(\mathrm{R} 1)$

Included gneiss (abundant: $\mathrm{SiO}_{2}, \mathrm{Al}_{2} \mathrm{O}_{3}, \mathrm{CaO}, \mathrm{Fe}_{2} \mathrm{O}_{3}$, $\mathrm{MgO}, \mathrm{Na}_{2} \mathrm{O}, \mathrm{K}_{2} \mathrm{O}$ ) and schist (are composed mainly of quartz + garnet+ muscovite + biotite + plagioclase \pm chlorite \pm opaque; abundant: $\mathrm{SiO}_{2}, \mathrm{Al}_{2} \mathrm{O}_{3}, \mathrm{CaO}, \mathrm{Fe}_{2} \mathrm{O}_{3}$, $\mathrm{MgO}, \mathrm{Na}_{2} \mathrm{O}, \mathrm{TiO}_{2}$ ), and amphibolites (the same as schist) (R2)

Abundant $\left(\mathrm{SiO}_{2}, \mathrm{Al}_{2} \mathrm{O}_{3}, \mathrm{CaO}, \mathrm{Fe}_{2} \mathrm{O}_{3}, \mathrm{MgO}, \mathrm{Na}_{2} \mathrm{O}\right)(\mathrm{R} 1)$

Evaporates minerals include gypsum, halite, and anhydrite. Carbonate minerals are dolomite, calcite, $\mathrm{Mg}$-calcite, and aragonite. Siliciclastic minerals are quartz, K-feldspars, and plagioclase $\left(\mathrm{SiO}_{2}, \mathrm{CaO}, \mathrm{SO}_{3}\right.$, $\mathrm{MgO}$, and $\mathrm{Al}_{2} \mathrm{O}_{3}$ )

Metasediments: high $\mathrm{Al}_{2} \mathrm{O}_{3}, \mathrm{CaO}, \mathrm{Fe}_{2} \mathrm{O}_{3}, \mathrm{MgO}, \mathrm{TiO}_{2}$, $\mathrm{Ni}, \mathrm{V}$, and $\mathrm{Cr}$; low $\mathrm{SiO}_{2}, \mathrm{Na}_{2} \mathrm{O}, \mathrm{Rb}, \mathrm{Ba}, \mathrm{Sr}, \mathrm{Zr}$, and $\mathrm{Y}$, where Tertiary olivine basalt composed of plagioclase, augite, and olivine $\left(\mathrm{SiO}_{2}, \mathrm{TiO}_{2}, \mathrm{~K}_{2} \mathrm{O}, \mathrm{MgO}\right)(\mathrm{R} 1, \mathrm{R} 3)$

Ferruginous sandstone and ironstone. The mineralogy includes goethite magnetite, quartz, illite, halite, kaolinite, dolomite, and vesuvianite. Abundant $\mathrm{SiO}_{2}$, $\mathrm{Fe}_{2} \mathrm{O}_{3}, \mathrm{Al}_{2} \mathrm{O}_{3}, \mathrm{CaO}, \mathrm{MgO}$ (R4) 
Table 5 Geology and geochemistry of water bearing formation and watershed affecting groundwater wells (Continued)

\begin{tabular}{|c|c|c|c|}
\hline \multirow[t]{2}{*}{ Well no. } & \multirow[t]{2}{*}{ Aquifer } & \multicolumn{2}{|l|}{ Water-bearing formation } \\
\hline & & Lithology & Geochemistry and/or mineralogy \\
\hline 24 & \multirow[t]{7}{*}{ Fractured basement } & Ophiolitic serpentine and talc carbonate & \multirow{2}{*}{$\begin{array}{l}\text { Include magnizite, chromite, dolomite, talc, and iron } \\
\text { oxides (geothite, hematite, magnitite). Abundant } \mathrm{Al}_{2} \mathrm{O}_{3} \text {, } \\
\mathrm{SiO}_{2}, \mathrm{Feo}, \mathrm{TiO}_{2}, \mathrm{CaMg}\left(\mathrm{CO}_{3}\right)_{2}, \mathrm{CaCO}_{3} \text {, and Fe-Ti } \\
\text { oxides (R1) }\end{array}$} \\
\hline 25 & & & \\
\hline 26 & & Acid volcanic & $\begin{array}{l}\text { Include rhyolite, rhyodacite, and dacite. High } \\
\text { concentrations of } \mathrm{SiO}_{2}, \mathrm{Na}_{2} \mathrm{O}, \mathrm{Fe}_{2} \mathrm{O}_{3}, \mathrm{~K}_{2} \mathrm{O}, \mathrm{Zr}, \mathrm{Nb} \text {, } \\
\text { and } \mathrm{Y} \text { but low in } \mathrm{MgO}, \mathrm{CaO}, \mathrm{Cr}, \mathrm{Ni}, \mathrm{Sr}, \mathrm{Ga} \text {, and } \mathrm{V} \text { (R5) }\end{array}$ \\
\hline 27 & & Metamorphic rocks & The same like well number 2 \\
\hline 28 to 35 & & Acid volcanic and metasediments & $\begin{array}{l}\text { Acid volcanic (the same as well number 26) } \\
\text { Metasediments (the same as well number 4) }\end{array}$ \\
\hline 36 & & \multirow[t]{2}{*}{ Older gray granite and acid volcanic } & \multirow{2}{*}{$\begin{array}{l}\text { Older gray granite (the same as well number } 1 \text { ) } \\
\text { Acid volcanic (the same as well number } 26 \text { ) }\end{array}$} \\
\hline 37 & & & \\
\hline
\end{tabular}

The geochemistry of the studied rocks is obtained from different sources as follows: (R1)—Hassan (2015), (R2)—Abd El-Naby and Frisch (2006), (R3)—Khalil (1997), (R4)-Farouk et al. (2015), (R5)—Shahin et al. (2016)

and their names were shown in (Figs. 1 and 7). Only eight basins are containing groundwater wells; the Nubian Sandstone Aquifer is concentrated in the Wadi Hodein Basin, while the wells of alluvial and basement aquifers are scattered inside other basins. These basins are representing the catchment areas affecting the existing groundwater wells. The hydrographic basins include high intensive drainage network (Fig. 10) which provides more chances for groundwater recharge from surface runoff. These drainage lines are controlled by fractures and/or faults which mean that the sites along the drainage lines are associated by structural lineaments. This condition facilitates chances for groundwater accumulation which can be recharged through surface-groundwater interactions. It is also noted that the recorded well were drilled along the drainage lines except well nos. 5 and 6 from the alluvial aquifer.

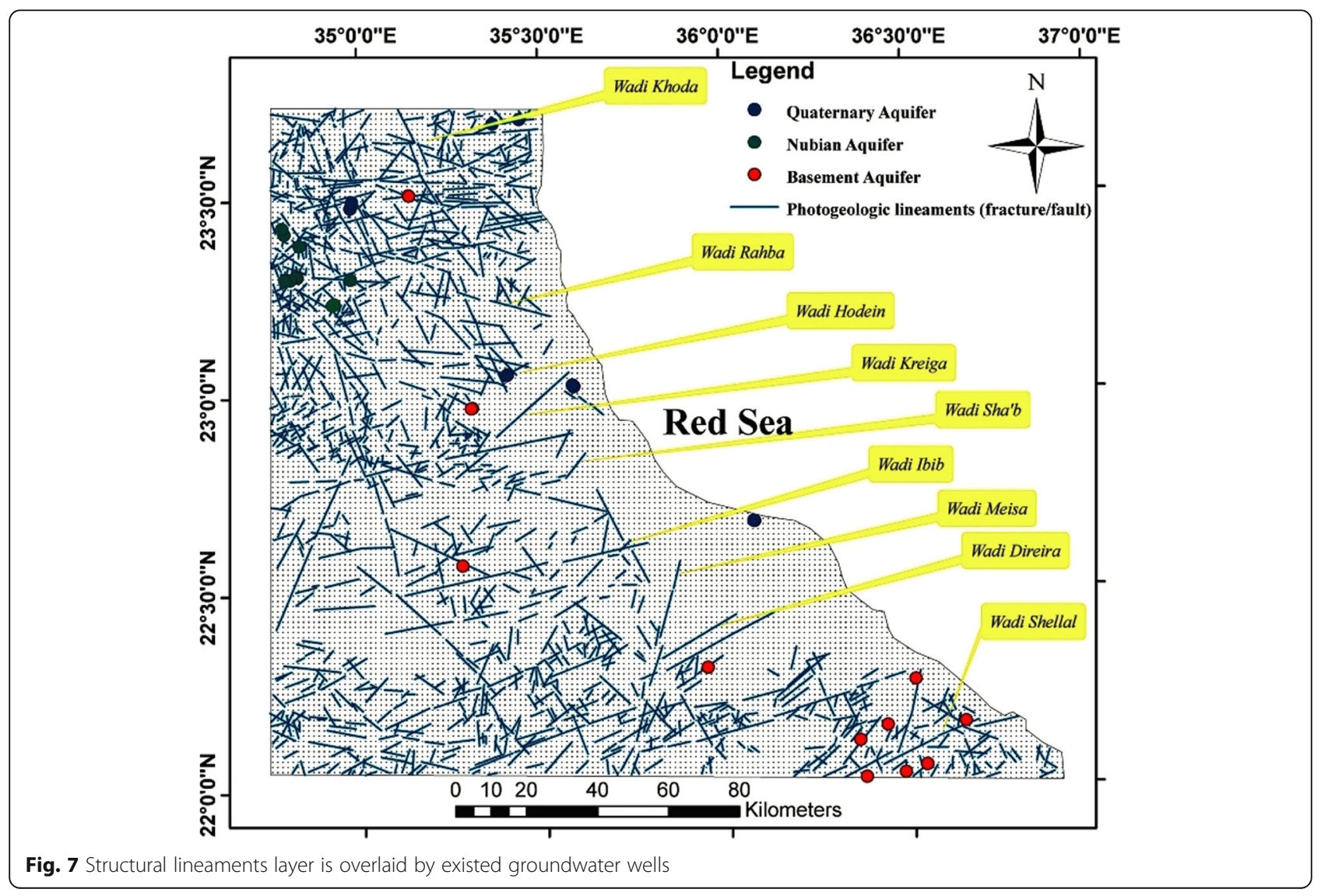




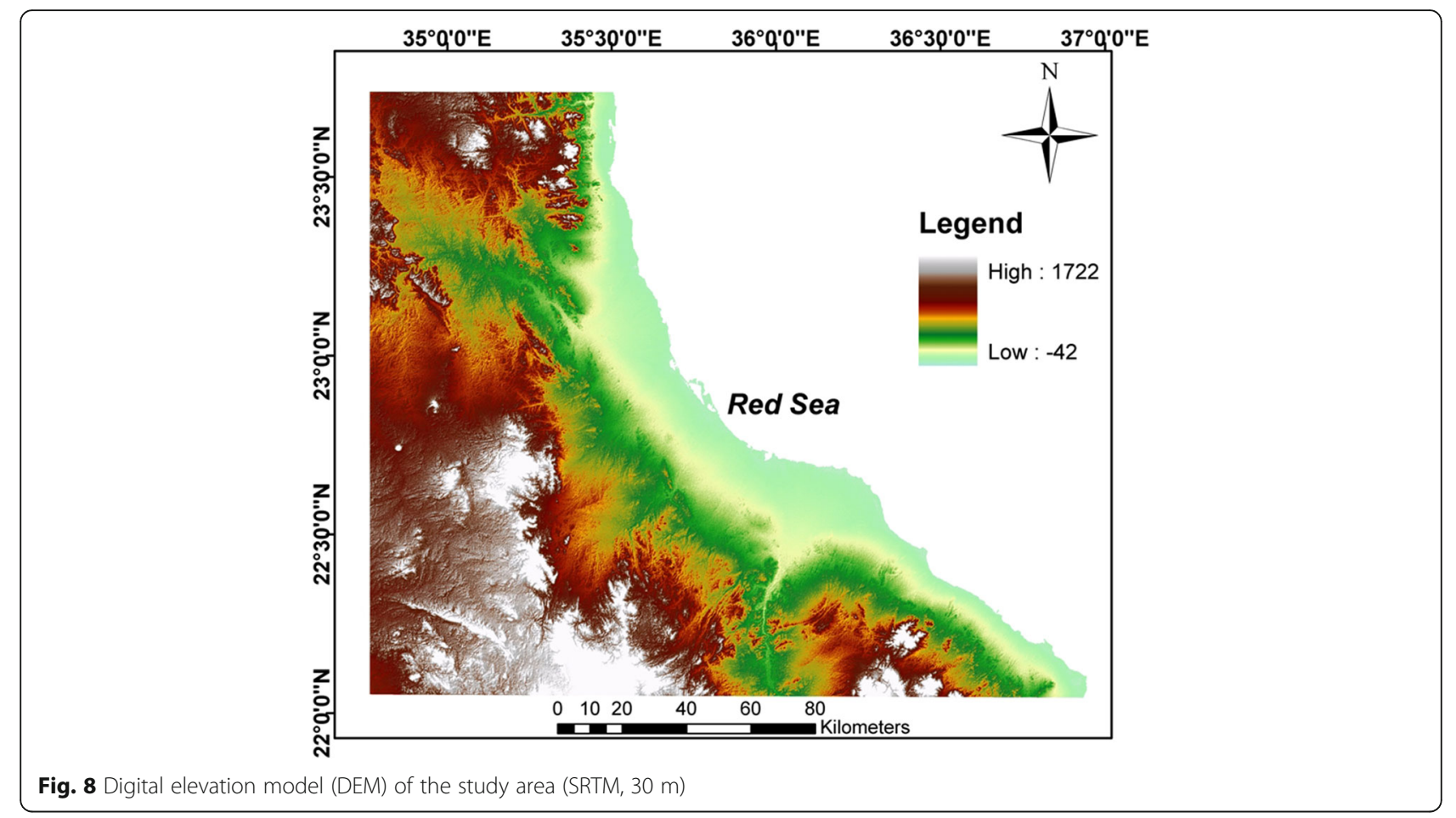

\section{Flow direction}

Flow direction is one of the important layers which contribute to the assessment of groundwater (Fig. 11). The layer of flow direction shows that surface water runs with the general slope with some exception for the isolated hilly areas where they direct surface water to the adjacent lower areas. The common flow directions have trends to the northeast and southeast. It noted that the recorded groundwater wells are located in the path of surface flow direction which supported the hypothesis of the current research.

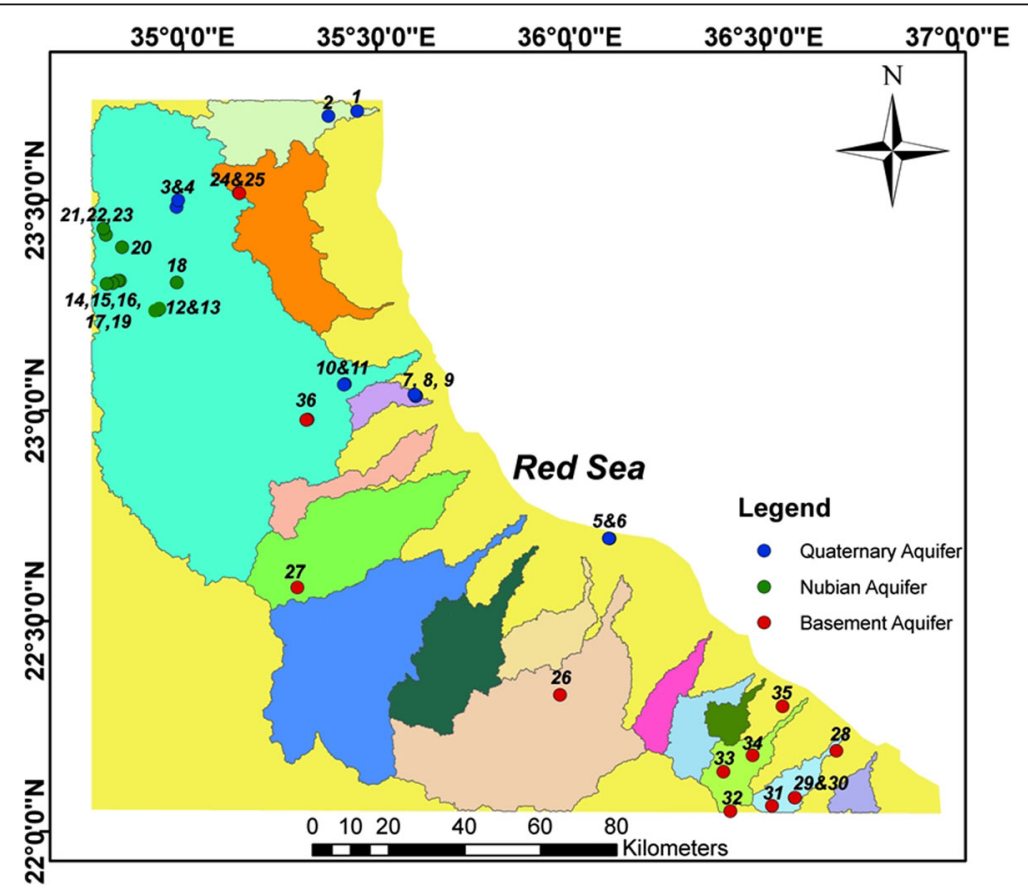

Fig. 9 Hydrographic basin of the study area extracted from DEM analyses 


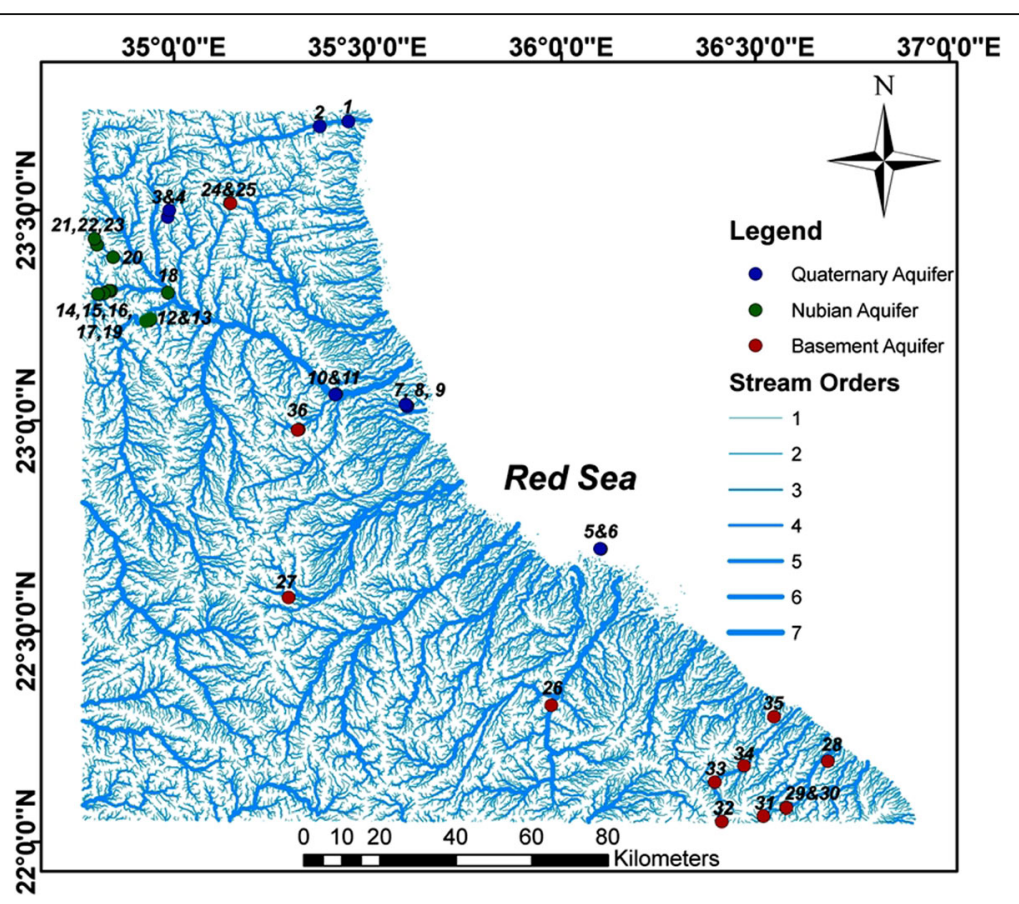

Fig. 10 Drainage network with stream orders of the study area

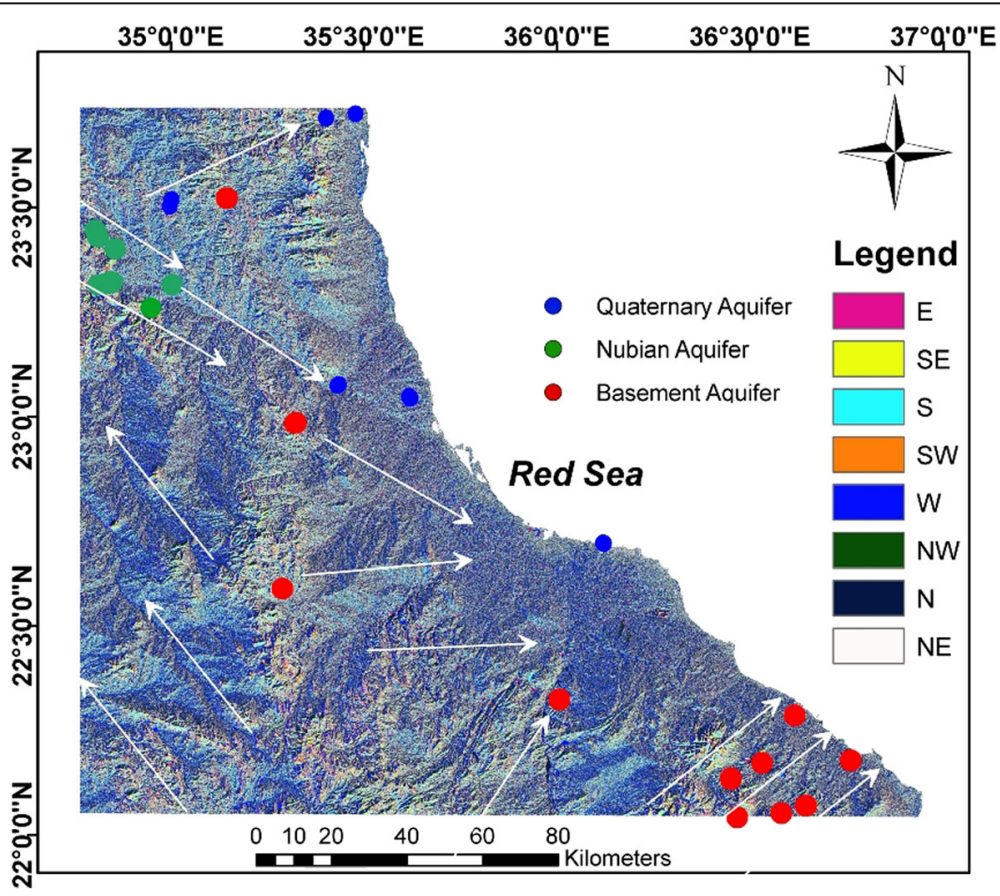

Fig. 11 Flow direction layer where that surface water runs with the general slope 


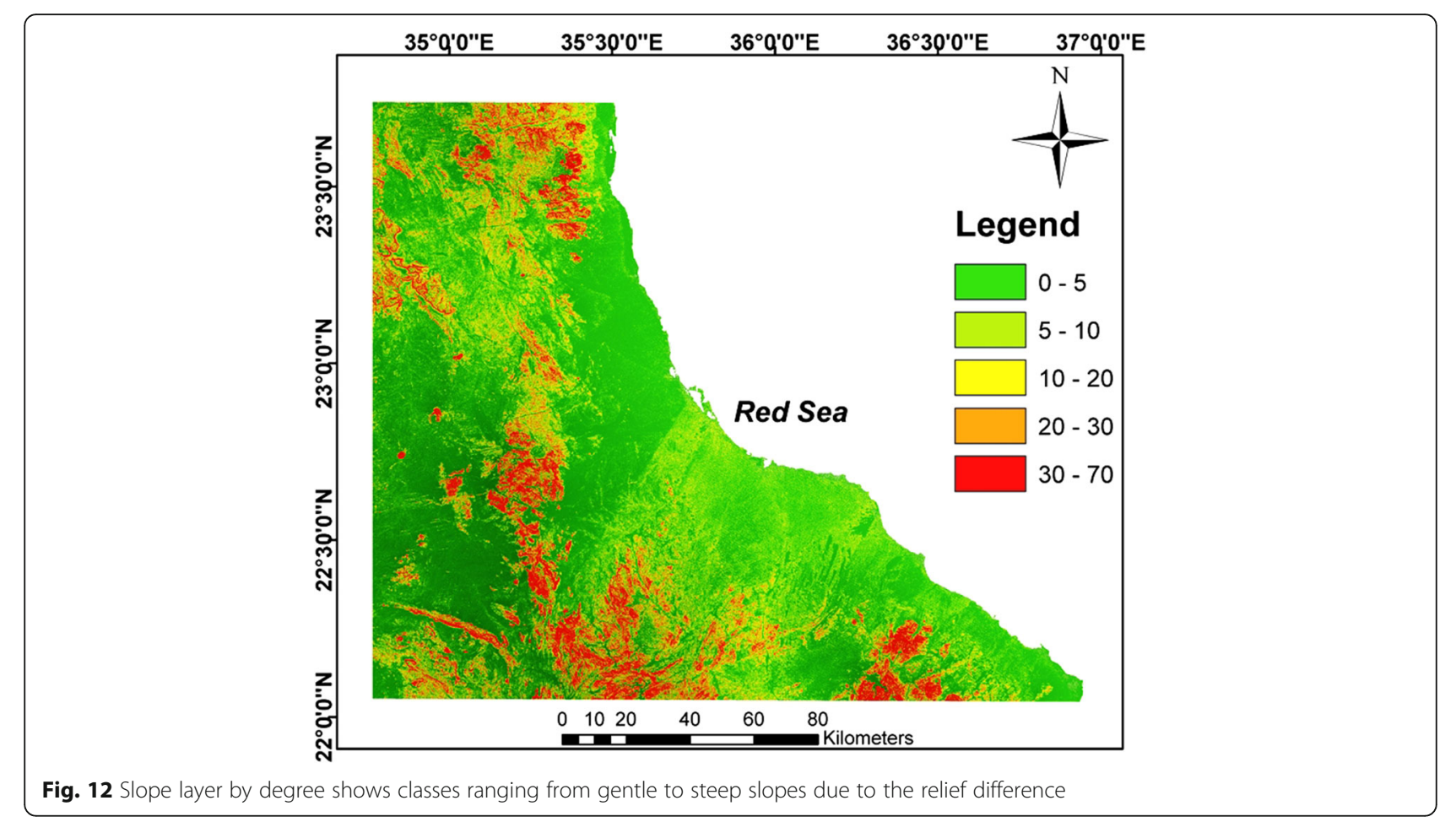

\section{Slope}

The slope layer shows (Fig. 12) the values vary between 0 and $10^{\circ}$ for the coastal plain and along the drainage lines and 20-70 for the Red Sea terrains and sedimentary blocks. The Red Sea terrains have steep slopes due to the relief difference while the coastal plain and drainage networks are acting as recharge areas.

\section{Discussion}

The chemical composition of groundwater is a combination of water constituents that migrate into the groundwater reservoir with recharge waters and a reaction of the groundwater body with the minerals present in the aquifer matrices (Yousif et al. 2016). The practice of environmental sustainability aims to secure the necessary requirements of the population without deterioration of the ability of the natural resources (such as groundwater) to meet the needs of next generations. Here, the current research is focusing on the environmental protection from the side of groundwater through the understanding of rock-water interaction.

\section{Rock-groundwater interaction and speciation modeling}

In general, multi-chemical processes occur during the rock-water interaction, such as dissolution and/or precipitation, but it is worthy to mention that other factors can also contribute to the groundwater chemistry like recharge amounts, seawater intrusion, and any source of pollution. Here, the research is focusing on the chemical composition of groundwater which is influenced by rock interaction.
Interpretation of chemical data suggests that the dissolution of $\mathrm{CaCO}_{3}$, ion-exchange processes, and weathering of minerals control the major ion chemistry of sodium, calcium, magnesium, and potassium. With the comparison between results in Tables 4, 5, and 6, it is clear that groundwater chemistry is guided by rocks influences where dissolution of minerals and accessory minerals are the main sources for major and trace elements. Taking into account, the study area is subjected to some rainy storms (the last heavy storm was recorded on 19 May 2017 where the rainfall continue for $2 \mathrm{~h}$ and resulted in surface runoff, this data was recorded through fieldwork) which lead to the recharging of the groundwater. The isotope analyses (oxygen 18 and deuterium) which carried out by Elewa (2000) confirmed the occurring of this recharging process. The freshwater supply to this area was depending on some natural springs from Nubian Sandstone exposures where the past historical reports mentioned that one of the French explorers (Linant de Bellefonds) recorded spring beside a temple cut into a mountainside that he saw in March 1832 in the southern part of Egypt's Eastern Desert (Sidebotham et al. 2004). This spring is still providing freshwater until the present which reveals the continue recharges to the Nubian sandstone aquifer. Therefore, the leaching and dissolution can be occurring through the interaction between the surface water and watershed rocks and also between water-bearing formation and groundwater. It is worth to mention that the recharge of the $\mathrm{Nu}$ bian Sandstone Aquifer is a process which is controlled by some factors. For example, in the Western Desert, recharge 
Table 6 Saturation indices of the studied groundwater samples, using PHREEQC geochemical model

\begin{tabular}{|c|c|c|c|c|c|c|c|c|c|c|c|}
\hline Well no. & Aquifer & $\begin{array}{l}\text { Aragonite, } \\
\mathrm{CaCO}_{3}\end{array}$ & $\begin{array}{l}\text { Calcite, } \\
\mathrm{CaCO}_{3} \\
\end{array}$ & $\begin{array}{l}\text { Dolomite, } \\
\text { CaMg }\left(\mathrm{CO}_{3}\right)_{2}\end{array}$ & $\begin{array}{l}\text { Alunite, } \\
\mathrm{KAl}_{3}\left(\mathrm{SO}_{4}\right)_{2}(\mathrm{OH})_{6} \\
\end{array}$ & $\begin{array}{l}\text { Gibbsite, } \\
\mathrm{Al}(\mathrm{OH})_{3}\end{array}$ & $\begin{array}{l}\text { Goethite, } \\
\text { FeOOH }\end{array}$ & $\begin{array}{l}\text { Hematite, } \\
\mathrm{Fe}_{2} \mathrm{O}_{3}\end{array}$ & $\begin{array}{l}\text { Iron(III) oxide- } \\
\text { hydroxide }\end{array}$ & $\begin{array}{l}\text { Magnetite, } \\
\mathrm{MnOOH}\end{array}$ & $\begin{array}{l}\text { Barite, } \\
\mathrm{BaSO}_{4} \\
\end{array}$ \\
\hline 1 & \multirow[t]{11}{*}{ Alluvial } & 0 & 0.09 & 0.31 & & 0.82 & 7 & 17 & & 13 & \\
\hline 2 & & 0 & 0 & 0 & 6 & 3 & 9 & 21 & & & \\
\hline 3 & & 0.61 & 0.75 & 1.75 & & 1.3 & 7 & 18 & & & \\
\hline 4 & & 0.66 & 0.8 & 2 & & & & & & & \\
\hline 5 & & 0 & 0.02 & 0.14 & 2 & 1.65 & 7 & 18 & & 13 & 0.4 \\
\hline 6 & & 0.24 & 0.39 & 0.89 & 0.35 & 1.44 & 7 & 18 & & 14 & 0.35 \\
\hline 7 & & & & & 4 & 8 & 2.59 & 20 & & 13 & \\
\hline 8 & & 0 & 0.08 & 0.1 & 3.44 & 2.32 & 8.49 & 20 & & 13 & \\
\hline 9 & & & & & 3.14 & 2.12 & 8.16 & 19.32 & & 12.76 & \\
\hline 10 & & 0 & 0.14 & & 1.68 & 1.31 & & & & 13.9 & \\
\hline 11 & & 0 & 0.07 & & 1.14 & 1.44 & 13.8 & & & & \\
\hline 12 & \multirow{12}{*}{$\begin{array}{l}\text { Nubian } \\
\text { Sandstone }\end{array}$} & & & & & 1 & 9 & 21 & 2 & 10 & \\
\hline 13 & & & & & & 2 & 9 & 21 & 4 & 20 & \\
\hline 14 & & & & & & 1.16 & 9.19 & 21.38 & 2.3 & 17.15 & \\
\hline 15 & & & & & & 1.77 & 9.51 & 22 & 2.6 & 17.5 & \\
\hline 16 & & & & & & 0.86 & 9.5 & 22 & 2.6 & 16.15 & \\
\hline 17 & & & & & & 1.44 & 8.24 & 19.48 & 1.34 & 17.6 & \\
\hline 18 & & & & & & 1.4 & 8.34 & 19.69 & 1.45 & 14.94 & \\
\hline 19 & & & & & & 1.42 & 7.92 & 18.84 & 1 & 14.79 & \\
\hline 20 & & & & & & 1.4 & 7 & 18 & 1 & 16.19 & \\
\hline 21 & & & & & & 1.4 & 7.92 & 17 & 1 & 15.67 & \\
\hline 22 & & & & & & 1.37 & 7.76 & 18.52 & 0.9 & 15.66 & \\
\hline 23 & & & & & & 1.4 & 7.53 & 18.07 & 0.7 & 13.82 & \\
\hline 24 & \multirow{14}{*}{$\begin{array}{l}\text { Fractured } \\
\text { basement }\end{array}$} & & & 0.58 & & & & 17.52 & & & \\
\hline 25 & & & & 0.53 & 0 & 0.67 & 8.45 & 19.9 & & & \\
\hline 26 & & 0 & 0.11 & 0.33 & 0.48 & 1.79 & 8.33 & 19.66 & & 16 & \\
\hline 27 & & & & 0.06 & 0 & 2 & 9 & 21 & & 16.27 & \\
\hline 28 & & & & & 1.89 & 1.61 & 7.95 & 18.9 & & 11.12 & \\
\hline 29 & & 0 & 0.05 & 0.09 & 0 & 1.31 & 7.62 & 18.25 & & & \\
\hline 30 & & 0 & 0.01 & & 0 & 1.49 & 8.22 & 19.45 & & 16.16 & \\
\hline 31 & & 0.19 & 0.34 & 0.44 & 0 & 1.48 & 6.98 & 16.97 & & 14.7 & \\
\hline 32 & & 0.22 & 0.37 & 0.68 & 1.7 & 1.64 & & & & 12.43 & 0.1 \\
\hline 33 & & 0 & 0.14 & 0.07 & 1.46 & 1.8 & & & & 14.79 & 0.25 \\
\hline 34 & & & & & 5.3 & 2.78 & 8.09 & 19.2 & & 13.33 & 0 \\
\hline 35 & & 0.04 & 0.19 & 0.09 & 1.47 & 1.19 & & & & & 0 \\
\hline 36 & & 0.04 & 0.18 & 0.24 & 0.62 & 1.41 & & & & 13.43 & 0 \\
\hline 37 & & 0.49 & 0.63 & 1.21 & 0.52 & 1.03 & & & & 13.26 & 0.02 \\
\hline
\end{tabular}

The + values of the saturation indices express the over-saturated phase, the 0 values of the saturation indices express the saturated phase

of this aquifer can happen under extreme precipitation over the Nubian watershed in Sudan and Chad or under a considerable rising of Lake Nasser levels (Ahmed and Abdelmohsen 2018).

The groundwater chemistry of this area is principally controlled by the mixing of waters, evaporation, mineral equilibrium, dissolution and deposition, and ion exchange processes (Dehnavi et al. 2011). The obtained results of saturation indices (SI) of minerals are useful for evaluating the level to which chemistry of water is controlled by the equilibrium with solid phases (Appelo and Postma 1993). The saturation indices (SI) of minerals that were expected 
to be responsible for the chemical composition of the recorded groundwater were investigated.

The obtained results of speciation modeling are summarized in (Table 6) where samples from the three studied aquifers were investigated. The three aquifers are supersaturated with respect to gibbsite $\left(\mathrm{Al}(\mathrm{OH})_{3}\right)$, goethite $(\mathrm{FeOOH})$, hematite $\left(\mathrm{Fe}_{2} \mathrm{O}_{3}\right)$, and magnetite $(\mathrm{MnOOH})$. All samples are supersaturated with gibbsite mineral due to the presence of aluminum in suspended fraction where the geochemistry of water-bearing formations and the rocks along the water path (Table 5) shows that $\mathrm{Al}_{2} \mathrm{O}_{3}$ is a common component. The investigation of Landsat images and geologic map with respect to the locations of groundwater wells (Figs. 3, 4, 5, and 6) shows the geology along the water path to these wells which composed of metasediments, metamorphic, and igneous rocks in case of alluvial and basement aquifers. The geochemistry of these rocks (Table 5) stated that $\mathrm{Fe}_{2} \mathrm{O}_{3}$ and $\mathrm{MgO}$ are abundant minerals. Therefore, their groundwaters are supersaturated with goethite, hematite, and magnetite. On the other hand, the outputs of speciation modeling with regard to Nubian Sandstone Aquifer showing homogeneity results where its groundwater samples are supersaturated with gibbsite, goethite, hematite, magnetite, and iron(III) oxide-hydroxide. These supersaturations and homogeneity in mineral indices resulted from ferruginous sandstone and ironstone which represent the water-bearing formation and also the main watershed which reacts with the surface water through its path to recharge groundwater. The other results of geochemical model clarify that groundwaters from both alluvial and basement aquifers are supersaturated with aragonite $\left(\mathrm{CaCO}_{3}\right)$, calcite $\left(\mathrm{CaCO}_{3}\right)$, dolomite $\left(\mathrm{CaMg}\left(\mathrm{CO}_{3}\right)_{2}\right)$, and alunite $\left(\mathrm{KAl}_{3}(-\right.$ $\left.\mathrm{SO}_{4}\right)_{2}(\mathrm{OH})_{6}$ ) (Table 6). In case of alluvial aquifer, the water-bearing formation consists of rock fragments of basement rocks and a mixture of carbonate minerals such as dolomite, calcite, Mg-calcite, and aragonite. Siliciclastic minerals are quartz, K-feldspars, and plagioclase, with minor heavy minerals and clays $\left(\mathrm{SiO}_{2}, \mathrm{CaO}\right.$, $\mathrm{Al}_{2} \mathrm{O}_{3}$, and $\mathrm{MgO}$ ). On the other side, the basement aquifer has a variety of rock content which includes acid volcanic, granite, ophiolitic metagabbro, and talc carbonate. These rocks are rich with $\mathrm{CaMg}\left(\mathrm{Co}_{3}\right)_{2}$, $\mathrm{CaCO}_{3}, \mathrm{CaO}$, and $\mathrm{K}_{2} \mathrm{O}$ which can be considered the main source for the saturation with carbonate minerals in groundwaters. However, rocks are generally classified as sedimentary, igneous, and metamorphic where minerals formed these rocks can be dissolved in the groundwater based on their resistance to the chemical weathering. These reactions between rocks and groundwater are depending on the initial water which in this case is represented by rainfall. Therefore, the current research conformed that the groundwater chemistry is the imprints of the rock-water interaction.

\section{Hydrogeochemical evolution and groundwater genesis} Piper's diagram (Piper 1944) in (Fig. 13) consists of three separate fields for plotting chemical data, two triangles at the lower right and lower left sides, and an intervening diamond shape for the projection. The major cations $\left(\mathrm{Ca}^{2}\right.$ ${ }^{+}, \mathrm{Mg}^{2+}$, and $\mathrm{Na}^{+}$plus $\mathrm{K}^{+}$) are plotted in the lower left triangle, while the major anions $\left(\mathrm{Cl}^{-}, \mathrm{SO}_{4}{ }^{2-}\right.$, and $\mathrm{CO}_{3}{ }^{2-}$ plus $\mathrm{HCO}_{3}{ }^{-}$) are plotted in the lower right triangle. The two points representing the cations and anions composition are then projected on the diamond-shaped field. Distinct groundwater quality types can be easily distinguished by their plotting in certain sub-areas of the diamond-shaped field. Piper's diagram suggested that the groundwater in the studied area have the meteoric origin of mineralization (precipitation and flash flood over the area) affected by leaching and dissolution, this is for few samples of the investigated aquifers of the study area. The ion dominance of this groundwater, especially in the Nubian sandstone aquifer, possessed the sequence of $\mathrm{Na}>\mathrm{Ca}>\mathrm{Mg}$ with $\mathrm{Cl}>$ $\mathrm{HCO}_{3}>\mathrm{SO}_{4}$. Most groundwater samples of alluvial, $\mathrm{Nu}-$ bian Sandstone, and fractured basement aquifers are affected by leaching and dissolution of marine deposits and considered mature water.

\section{Groundwater protection and development (recommendation)}

In arid and hyper-arid regions, groundwater can be considered the sole source of water for domestic, industrial, and agricultural needs. The development and protection of this precious source are a prerequisite for both potential contamination and overexploitation. Therefore, the understanding of the hydrogeologic and geologic settings as well as the factors which affect the groundwater occurrences and quality are in dire needs. Knowledge of aquifer lithology and identification of geology along the flow path to the groundwater wells, in addition to investigations of different thematic layers related to groundwater accumulation, was used to summarize some recommendations. Based on field investigations, remote sensing data, geologic situation, geomorphologic setting, hydrologic parameters of the recorded well data, groundwater chemistry, and the thematic layers (structural lineaments, DEM, hydrographic basins, drainage lines, flow direction, and slope), the following suggestion can be applied:

1. Priority map for groundwater exploration is proposed for both hydro-geophysical investigation and test drillings in order to evaluate the potential of groundwater (Fig. 14). This map was created according to the results of the multidisciplinary data layer analysis of this study by using Arc GIS software. It is expected that the very high and high priorities have a good potential for groundwater 

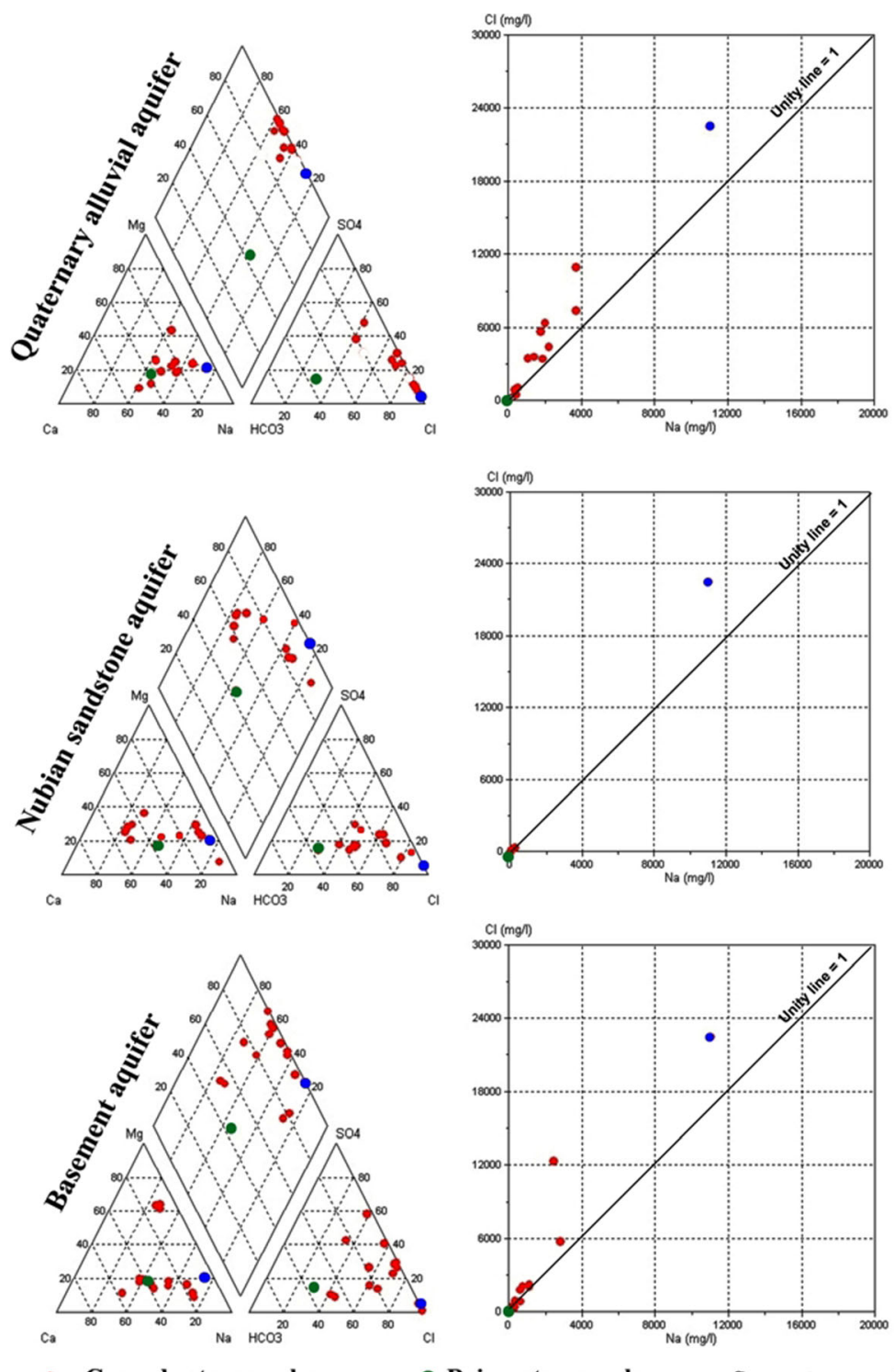

- Groundwater samples

- Rain water sample

- Sea water sample

Fig. 13 Groundwater wells from the studied aquifers plotted on Piper diagram and scattered plot of $\mathrm{Na}-\mathrm{Cl}$

recharge based on the criteria such as density of structural lineaments (faults and/or fractures) which provide more chance for groundwater recharge, low slope, permeable soil type, position along the drainage network, elevation, and flow direction. The drainage lines and flow direction also support the chances for recharge. The low elevation and low slope values are increasing the residence time of surface water and hence providing good conditions for water accumulation. The increasing of residence time in fractured areas which have a low slope and elevations raise the possibility of recharge processes. In case of basement aquifer, the design for determination of the priorities for exploring groundwater was depending mainly on careful investigation of the structural lineaments with regard to their orientation, and the density of the intrusive dykes where it acts as a barrier of the percolated water. The intersected fractures with each other's and intrusive dykes are providing high possibility environments for groundwater entrapments. Therefore, these areas are suggested for future drilling.

2. The coastal plain and some parts of Piedmont Plain as wells as intermountain areas have low and very low priorities (Fig. 14) due to low fracture density and the possibility of seawater intrusions which can be increased with aquifer discharging. 


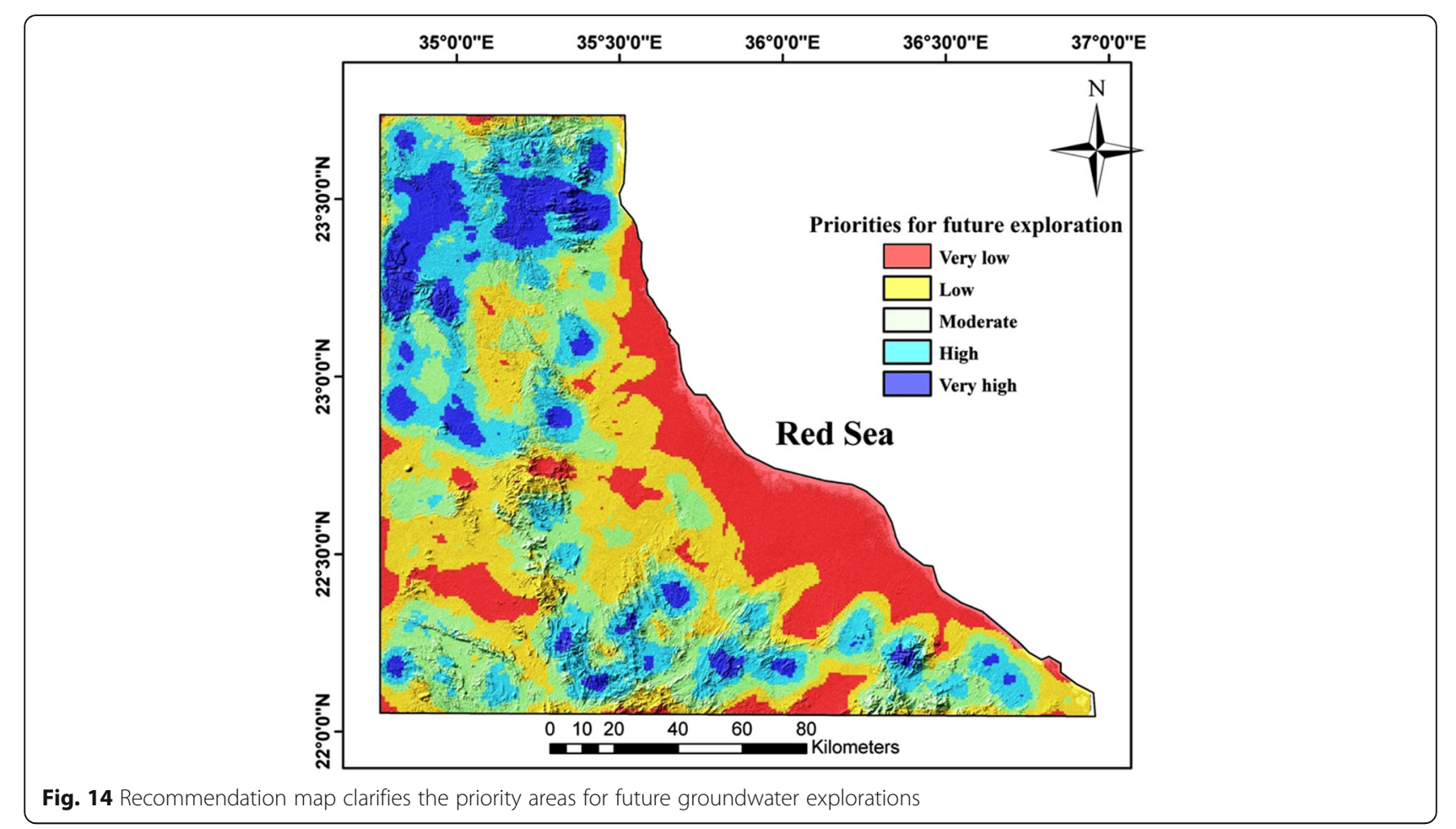

3. The obtained data about the recorded wells were used to calibrate the priority map (Fig. 14). With regard to TDS values, the wells which are producing a freshwater (such as, well nos. 12, 14, $15,16,17,18,19,20,21,22,23,24,25,27,29$;

Table 1) are located in the areas with priority classes from high to very high (compare Fig. 10 "drainage with wells locations" with Fig. 14), which confirm the basics for creations of the priority map.

4. The obtained results showed that the people in the study area are suffering from water shortage problem, and the available water resources are polluted by heavy metals and/or maybe microbial pollutants. The trace element concentration of the investigated groundwater samples showed some values exceed the permissible limit (according to EHCW 2007) which represent a health hazard in case of drinking that water. We also noticed a thick layer of green algae covered the pool that collected water from Abu Safa spring (Fig. 1c) of the Nubian Sandstone Aquifer, which can be considered a source of pollution. Therefore, we suggest that the government can install some water treatment plants especially near the polluted freshwater resources (Wadi Abu Safa) to remediate the pollution in these water springs. Also, we suggest installing photoreactors that can be used in this remote area for water purification and disinfection via the photo-catalysis technique as one of the advanced oxidation processes without any byproduct.
5. The best solution to overcome the saline and brackish water is the installation of the desalination plant. In such cases, the desalination of this groundwater provides coast reduction than desalination of seawater. Desert Research Center and Egypt Desalination Research Center of excellence have the required experiences to install small mobile water desalination plants using solar power. These small plants are considered the suitable solution for the high salinity problem in the study area.

6. Well nos. 12 and 13 of Nubian Sandstone Aquifer are very adjacent to each other, where the salinity values show the wide difference (TDS for well 12 is $776 \mathrm{mg} / \mathrm{l}$ and for well 13 is $14,388 \mathrm{mg} / \mathrm{l})$. The review of the drilling reports of both wells stated that after $120 \mathrm{~m}$ (in case of well no. 12), the sandstone was completely affected by hydrothermal solutions which maybe came out through the fracture. This solution is very rich with minerals and salts and led to lost or reduces the porosity and permeability and also increase the salinity of groundwater (as in case of well 13). Therefore, it is recommended to avoid installation of screens in front of any sandstone affected by hydrothermal solutions during the design of any wells penetrate the Nubian Sandstone Aquifer. Shallow depths between 90 and $120 \mathrm{~m}$ can provide good potential and quality of groundwater, taking into account cost reduction. 


\section{Conclusions}

This study presents an example from a hyper-arid area on the Eastern Desert of Egypt where a combination of multidiscipline was applied to describe the rock-water interaction by testing the ability of remote sensing data to provide details about the geology affecting each groundwater well. In general, multi-chemical processes occur during the rock-water interaction, such as dissolution and/or precipitation, but other factors can also contribute to the groundwater chemistry like recharge amounts, seawater intrusion, and any source of pollution. Here, the research is focusing on the chemical composition of groundwater which is influenced by rock interaction. Interpretation of chemical data suggests that the dissolution of $\mathrm{CaCO}_{3}$, ion exchange processes, and weathering of minerals controls the major ion chemistry of sodium, calcium, magnesium, and potassium. However, rocks are generally classified as sedimentary, igneous, and metamorphic where minerals formed these rocks can be dissolved in the groundwater based on their resistance to the chemical weathering. These reactions between rocks and groundwater are depending on the initial rainfall; therefore, the current research conformed that the groundwater chemistry is the signature of the rock-water interaction. The leaching and dissolution can occur through the interaction between the surface water and watershed rocks and also between water-bearing formation and groundwater. The integration of remote sensing and GIS application is showing great efficiency in the knowledge of lithologic nature and identification of geology along the flow path to the groundwater wells. Also, these applications provide different thematic layers related to groundwater accumulation (geomorphologic setting, hydrologic parameters, groundwater chemistry, and the thematic layers such as structural lineaments, DEM, hydrographic basins, drainage lines, flow direction, and slope) which can be used for the determination of the priorities for exploring groundwater. The current scientific approach can be considered a replicable model which can be applied in the hyper-arid environment under the same conditions.

\section{Acknowledgements}

It is a pleasure to acknowledge the Egyptian Desalination Research Center of Excellence, EDRC) which follows Desert Research Center, for their supporting to carry out this research.

\section{Availability of data and materials}

All data generated or analyzed during this study are included in this manuscript.

\section{Authors' contributions}

MY studied the geology of the study area, analyzed and interpreted different satellite images and digital elevation models, prepared the maps through the applications of GIS, and run the geochemical model. AHE-A performed the chemical analyses of the groundwater, collected the groundwater samples, and calculated the hypothetical salts. Both authors wrote, reviewed, and approved the final manuscript.

\section{Authors' information}

Mohamed Yousif is an associate professor of hydrogeology, Geology Department, Desert Research Center. The research interest is focusing on the applications of remote sensing and GIS for groundwater exploration.

His publication list is available on Google Scholar site (https://scholar.google.com/ citations? user=iHmSezgAAAAJ\&hl=en).

Abdel Hameed El-Aassar is an associate professor of water chemistry, Hydro-geochemistry Department, Desert Research Center. The research interest is focusing on groundwater chemistry and water desalination.

Ethics approval and consent to participate

Not applicable

Consent for publication

Not applicable

\section{Competing interests}

Both authors declare that they have no competing interests.

\section{Publisher's Note}

Springer Nature remains neutral with regard to jurisdictional claims in published maps and institutional affiliations.

\section{Author details}

${ }^{1}$ Geology Department, Desert Research Centre, P.O. Box 11753, El Matariya, Cairo, Egypt. ${ }^{2}$ Hydrogeochemistry Department, Desert Research Centre, P.O. Box 11753, El Matariya, Cairo, Egypt.

Received: 17 June 2018 Accepted: 8 August 2018

Published online: 03 September 2018

\section{References}

Abd El-Naby H, Frisch W (2006) Geochemical constraints from the Hafafit Metamorphic Complex (HMC): evidence of Neoproterozoic back-arc basin development in the central Eastern Desert of Egypt. J Afr Earth Sci 45:173-186

Abdel Moneim AA (2005) Overview of the geomorphological and hydrogeological characteristics of the Eastern Desert of Egypt. Hydrogeol J 13:416-425

Ageeb GW, Kotb MM, Rahim IS (2007) Soil mapping of Wadi Hodein area, southeastern Egypt using remote sensing and GIS techniques. Aust J Basic Appl Sci 1(4):793-800

Ahmed, M., Abdelmohsen, K., 2018. Quantifying modern recharge and depletion rates of the Nubian Aquifer in Egypt. Surv Geophys (2018) 39:729-751. https://doi.org/10.1007/s10712-018-9465-3

American Society of Testing and Materials (ASTM) (2002) Water environmental technology, annual book of ASTM standards, sec. 11.01 and 11.02. U.S.N., West Conshohocken

Appelo CAJ, Postma D (1993) Geochemistry, groundwater and pollution. Balkema, Rotterdam

Conoco C (1987) Geological map of Egypt, scale 1:500,000-NF 36 NE-Bernice, Egypt. The Egyptian General Petroleum Corporation, Cairo

Dehnavi AG, Sarikhani R, Nagaraju D (2011) Hydro geochemical and rock water interaction studies in east of Kurdistan, N-W of Iran. Int J Environ Sci Res 1(1): $16-22$

Egyptian Higher Committee for Water (EHCW), 2007. Egyptian standard for drinking water and domestic uses (in Arabic)

Elewa HH (2000) Hydrogeology and hydrological studies in Halaib-Shalatin area, Egypt, using remote sensing technology and other techniques. Ph.D thesis, Faculty of Science, Ain Shams University, p 281P

Embaby Al, Razack M, Lecoz M, Porel G (2016) Hydrogeochemical assessment of groundwater in the Precambrian rocks, South Eastern Desert, Egypt. J Water Resour Prot 8:293-310. https://doi.org/10.4236/jwarp.2016.83025

Farouk S, El-Rahmany M, El-Desoky H, Khalil A, Fahmy W (2015) Geochemical characteristics of goethite-bearing deposits in the Dakhla-Kharga oases, Western Desert, Egypt. IJSEAS 1(1):72-87

Gheith H, Sultan M (2002) Construction of a hydrologic model for estimating Wadi runoff and groundwater recharge in Eastern Desert, Egypt. Hydrol J 263:36-55 J Agric Res 31(4B):1677-98

Hassan MA (2015) Basement rocks of Egypt, 1st edn. Assiut University, Geology Department 
Hassanein AK, Grais YL, Behiry EMK, Khider MH (2004) Origin, mode of formation of uniformity studies on soils of some physiographic units of Halaib and Shalateen area, Egypt. Zag J Agric Res 31(4B):1677-1698

ICARDA (International Center for Agricultural Research in the Dry Areas) (2010) Map of West Asia and Egypt, Absolute change of annual aridity index 20102040/current climate. Available online at: http://geoagro.icarda.org/en/cms/ metadata/index/563/West\%25252BAsia\%25252Band\%25252BEgypt.\%25252 BAbsolute\%25252Bchange\%25252Bof\%25252Bannual\%25252Baridity\%25252 Bindex\%25252B2010-2040\%25252F\%25252Bcurrent\%25252Bclimate

Khalil E (1997) Ocean-arc contenental margin volcanics sequence of Pan-African Precambrian belt, Egypt. Geochemical approach. Egypt J Geol 41/2B:477-528

Khalil MH (2014) Detection of magnetically susceptible dyke swarms in a fresh coastal aquifer. Pure Appl Geophys 171:1829-1845 Springer, Basel

Mohamed A, Sultan M, Ahmed M (2017) et al, Aquifer recharge, depletion, and connectivity: inferences from GRACE, land surface models, geochemical, and geophysical data. GSA Bull. https://doi.org/10.1130/B31460.1

Parkhurst DL, Appelo CAJ (1999) User's Guide to PHREEQC (Version 2)-a computer program for speciation, batch-reaction, one-dimensional transport, and inverse geochemical calculations, United States Geological Survey, Water Resources Investigations Report 99-4259, Washington DC, p 326

Piper AM (1944) A graphic procedure in the geochemical interpretation of water analyses. Trans Am Geophys Union 25(6):914-923 Washington DC

Shahin HA, Masoud S, Bayoumi M (2016) Geology, geochemistry and radioactivity of granitic and volcanic rocks at Hadarba area, South Eastern Desert, Egypt. Int Res J Geol Min 6(2):038-052

Shawky HA, Said MM, El-Aassar AM, Kotp YH, Abdel Mottaleb MSA (2012) Study the chemical characteristics of groundwater to determine the suitable localities desalination processes in the area between Mersa Alam and Ras Banas, Red Sea coast Eastern Desert, Egypt. J Am Sci 8(11):93-106

Sidebotham SE, Mikhail GT, Harrell JA, Bagnall RS (2004) Water temple at Bir Abu Safa (Eastern Desert). J Am Res Cent Egypt 41:149-159

Soussa H, El Feel AA, Alfy SZ, Yousif MSM (2012) Flood hazard in Wadi Rahbaa area, Egypt. Arab J Geosci 5:45-52

Yousef AF, Salem AA, Baraka AM, Aglan OS (2009) The impact of geological setting on the groundwater occurrences in some Wadis in Shalatein - Abu Ramad Area, South Eastern Desert, Egypt. Eur Water Pub (EWRA) 25(26):53-68 Yousif M, van Gelder R, Bubenzer O (2016) Hydrogeological investigation of shallow aquifers in an arid data-scarce coastal region (El Daba'a, northwestern Egypt). Hydrogeol J 24:159-179

\section{Submit your manuscript to a SpringerOpen ${ }^{\circ}$ journal and benefit from:}

- Convenient online submission

- Rigorous peer review

- Open access: articles freely available online

- High visibility within the field

- Retaining the copyright to your article

Submit your next manuscript at $\boldsymbol{\nabla}$ springeropen.com 